Article

\title{
A Methodological Framework Based on the Dynamic-Evolutionary View of Heritage
}

\author{
Iva Mrak
}

Faculty of Civil Engineering, Radmile Matejčić 3, Rijeka 51000, Croatia;

E-Mail: ivamrak@hotmail.com; Tel.:+385-91-550-8924

Received: 6 September 2013 / Accepted: 10 September 2013 / Published: 23 September 2013

\begin{abstract}
The paper describes the shifting perspective from the contemplative view to the dynamic-evolutionary view of heritage and the main characteristics of the resulting multi-criterial decision-aid tool for the evaluation of heritage. With the integration of conservation in planning processes and with opening of the procedures to public participation, there is a need for decision-aid tools that can help increase rationality and transparency in decision-making processes related to planning. By understanding the contemporary view of heritage and the landscape, it is possible to create tools capable of accounting for spatial complexity and the extant cultural, social, historic and economic relations. With this in mind, a specific tool was created that can be used for the analysis, diagnosis, evaluation and monitoring of spatial heritage (registered and under consideration for protection), identifying opportunities, defining strategies for heritage management processes, and in the creation and evaluation of development and management scenarios. The paper illustrates a shift in the consideration of heritage in spatial planning and presents an application of the developed model in a case study.
\end{abstract}

Keywords: multi-criteria evaluation; heritage; planning; decision-aid tools; criteria; indicators; strategies

\section{Introduction}

The contemporary landscape is characterized by a strong presence of stratified signs, emergencies, heritage history, lifestyles, functions and conflicts. In order to create the opportunities that put together different territorial, economic and cultural factors, interventions in such a landscape have to take into account the presence of material and intangible heritage, new modes of institutional organisation and governance, sources of financing and a complex and participatory social reality. Without a logical, 
rational and coherent method, rooted in knowledge of the complexity of the extant physical and social environment, there is the very real risk of arbitrary intervention in the landscape. Such arbitrary planning can lead to erasure of stratified significance, failure to reach the proposed goal or the creation of unforeseen impacts in different social sectors, thereby missing the inherent opportunities for creative interventions that are not mere repurposing, but that can also serve as a basis for development.

The first part of the paper describes the main issues needed to consider the shifting perspective from a contemplative ("bounding") to a dynamic-planning view of the heritage. The second part considers some existing decision-aid tools and proposes a model that connects illustrated theoretical concepts in an analysis-diagnosis evaluation tool for management of spatial heritage that can help the creative use thereof in the perspective of sustainable development. The third part illustrates the functioning of the proposed model and an application case.

\section{Research Approach, Objectives and Expected Results}

The research carried out attempts to give an ample, unsimplified vision of spatial heritage and at the same time to produce a manageable and truly useable model for the management of heritage and its integration in spatial planning. The proposed objective of the research was methodological, the creation of an evaluation model for the management of territorial heritage based on modular, flexible multi-criterial analyses, able to define functional preferences in difficult decisional and territorial contexts, as in the transformation of a contemporary landscape characterized by the strong presence of heritage and conflicts of interest.

To function in a complex contemporary context, a decision-aid model has to be rooted in the concepts of sustainable spatial management, considering the different dimensions of sustainability of development (environmental, economic and social), with particular attention paid to the extant, both heritage-wise and social. In particular, spatial heritage is considered in its most ample sense, material and intangible, and in the sense of different spatial categories (archaeological sites, architectural complexes, urban or rural areas and others). The social dimension is tied to the residents, to participation of the public in decision processes and to promoters of programmes and investments. The basis for the proposed model was found in models of multi-criteria and multi-objective evaluation, capable of disaggregating the evaluation issues. Multi-criteria and multi-objective evaluation techniques help to address the complexity of evaluated objects and processes.

The research attempts to further develop multi-criterial analysis models and to integrate multi-objective and multi-criteria evaluations with analysis of impact distribution for the social sectors, along with techniques for preference identification in the management of areas of complex social and heritage transformation.

The multi-criterial model proposed should be particularly useful in analysis of the development of the complex and stratified environment, and able to cover ample zones of transformation, individual interventions and choices of position based on the modular and flexible characteristic of the model.

In this way, the proposed model would also be the basis for the development of further models, especially through its capacity for continual evolution and particularly by integrating technological innovations in the collection, management and communication of data. 
The expected result of the research was the creation of a manageable and truly useable evaluation model for analysis, diagnosis and evaluation of the state of heritage, definition of the strategies of intervention and decision-aids in the planning and programming of intervention and management strategies of territorial heritage. The model could also be the basis on which to carry out the monitoring of the characteristics and management opportunities of the heritage, both in the short and long term.

Being a modular and flexible model it is proposed as the basis for the development of other models, adapted to the context, availability of data and advancement in the technologies of data collecting and processing and the techniques of communication with different types of end-users and public.

\section{From the Contemplative View of the Heritage to the Dynamic-Evolutionary Planning Perspective}

\subsection{Heritage and Conservation in Contemporary Society}

The first step in correctly framing the multiplicity of questions related to heritage management is to understand the contemporary view of heritage and the complex issues related to it.

Based on the concept of "social construction of reality" [1] from the social sciences, in recent times there has been a shift from a consideration of heritage as a fixed list to a socially open process [2]. The recognition of heritage (for example, Lichfield considers cultural heritage as "that which expresses some indefinable but recognizable element which the current society values especially and which it would wish to pass on to posterity" [3]) develops through the interaction of different actors (social sectors) [3], is based on different values and is explained by different disciplinary fields. In the sociological disciplines culture is seen as a set of values, beliefs and symbols of expression, and in anthropology it is seen as the way of life of the society [4]. On this path lies the conception of heritage as a social process based in the present and regarding the future, where the heritage is revaluated by each generation and the conservation process can be seen as the production of future heritage [5]. Nevertheless, to facilitate the communication and operation, some conventions are still given on an international level regarding the understanding of what constitutes cultural heritage, such as UNESCO's Convention Concerning the Protection of the World Cultural and Natural Heritage (Paris, 1972) or UNESCO's Convention for the Safeguarding of the Intangible Cultural Heritage (Paris 2003).

With the evolution of the concepts of heritage and conservation, the realization emerges that the contemporary landscape is a stratified complex of signs, elements and tangible and intangible relations [6]. Understanding heritage and its relations to development becomes crucial to maintaining continuity in transformation and spatial development.

The presence of cultural and natural heritage diminishes the perception of interruption of spatial and temporal continuity and allows a steady flow from past to present and future, a requirement for transformation without social trauma [7]. Heritage may be the basis of the attractiveness of the landscape at the time of cultural standardization; it can improve social and cultural integration and provide input to the creation of collective spaces.

Built cultural heritage (historic buildings, urban and rural sites, ethnological sites...) is often strongly related to intangible cultural heritage (customs, activities and traditions), both in urban and rural environments, and therefore participates in the construction of the identity of individuals and communities. Often the original use of the built heritage is no longer feasible, bringing forth the need 
for new rules, uses and management of the elements. This new use can be related to some other traditional or new form of cultural use, but also the introduction of completely new uses can be required, influencing the process of production of future cultural heritage.

Material and immaterial cultural heritage is a carrier of cultural significance, so its richness and diversity contribute to the creation of social capital [8,9]. Conservation of cultural heritage, combined with different types of cultural and economic activities, represents the basis of the creation of present and future heritage, new cultural and economic production related to culture (design but also agriculture or new skills), creative industries and cultural tourism.

In the process of conservation and management of heritage, it becomes increasingly important to identify different social and cultural sectors, their representation and the possible improvement of the managing process in order to optimally represent the values of different groups, respecting the criteria of sustainable development.

\subsection{Economics of Heritage}

Cultural economics are developed from environmental economics, but are not based on a compact theoretical model of culture. The concept of cultural capital is based on that of natural capital from environmental economics, and ecosystemic functioning is seen as a basis for maintaining environmental quality and biodiversity. As the natural capital produces the flow of environmental services, so the cultural capital produces the flow of cultural and monetary services.

The value of cultural heritage is often closely linked with artistic value, which also presents a "problematic" character-i.e., lack of purpose - that does not fall into the economic or moral categories, and whose management involves a balance between the categories of efficiency, fairness and beauty [10]. Cultural goods may be private, public or collective property and are characterized by externalities. The benefits arising from the cultural goods can be private, public and collective [11]. The public and merit character of cultural heritage presents known problems and opportunities related to the economics of public and common goods (such as: free riding, non-rivalry, non-excludability, market failure, ecosystemic character, property right, third sphere...). In this process, the cultural and economic values influence one another, forming different processes to the one traditionally given in economics, where the preferences can be considered as given.

Assessing the social and cultural values requires evaluations that differ from economic evaluations. The social value exists in an intrinsic way and cannot be represented by the market price. For example VSC (Valore Sociale Complesso = Complex Social Value) defined by Fusco Girard and Nijkamp [12]: Complex Social Value is assessed by the economic and extra-economic evaluations and is important for the identification of sustainable use. What Total Value of ecosystems and Complex Social Value have in common is that they cannot be expressed by monetary values only but necessitate multicriteria evaluations. The presence of cultural heritage contributes to stability of urban (and human) ecosystem (maintenance of identity, unification, social stability...). This social quality can be defined as the intrinsic value "I" of the cultural built heritage. It has economic reflections but it cannot be expressed in pure monetary terms. Complex Social Value can be expressed as VSC $=($ VET,I), the total economic value perceived by the community [12]. This complex value is best expressed through 
multi-criteria evaluations, which can take into account the objectives of all social sides as well as types of use and non-use values.

Because of the growth of heritage (due to historical addition and broadening of the definition of heritage), many interventions have to be made with limited resources and a consequentially low level of conservation. The risk is even more serious in cases where the heritage is exposed to erosion due to overuse. Therefore conservation presents multiple paradoxes: the economic capacity of conservation decreases with increasing commitment to conservation; conservation, considered as maximizing the capability of choice for future generations, involves minimizing the consumption choices of the present generations; and funds devolved to one asset are subtracted from another [13].

The interventions of conservation and requalification of heritage, especially on a large scale, involve multiple stakeholders: private investors, residents, government, visitors and the general public. For each group of stakeholders, interventions have financial and economic costs and benefits. Many of these costs and benefits are expressible in monetary and extra monetary terms, but others, especially in cases of large areas or objects of particular value, can only be seen as externalities not directly calculable in only monetary terms for each stakeholder.

The requalifications create tourist attractions and have positive effects on image and growth of market values (for example in the development of products, attracting new businesses...). The bound context, however, also involves extraordinary costs for the owners of the property due to the conservation, management and use of the property which is subject to restrictions, compared to the use of unbound property or other types of possible investments (opportunity cost). The investor is therefore interested in the possible direct (subsidies and matching grants) and indirect incentives (based on property or production tax, subsidy of interest or similar) [14] oriented to help in supporting the extraordinary costs of conservation and heritage management.

The collaboration between different entities can result in public-private, public-public or even public-private-social partnerships. In expectation of positive spillover effects on the environment, the good is managed by joint forces, where investments can be borne in equal (or similar) shares or where one party bears the image and the other financial investments, organisational skills and reputation. The first case is that of the public-private partnership which has not always led to major benefits for the public sector. The case of Baltimore, for example, has been criticized for enormous public spending, positive impact on a very limited area, lack of social justice, low quality of jobs obtained, gentrification, social polarization and dependence on continuous injections of public funds [15]. The letter case is for example, this case of the Guggenheim Museum in Bilbao, where the investment of construction and redevelopment was supported by the public sector but the effect of the reputation of the museum has had important spillover effects on the local context [16].

The effects of heritage and investments in its management can also be particularly evident where supply meets the cultural and non-cultural usage demand, such as in the art cities [17]. In these cases, non-cultural operators gain from the presence of cultural heritage, and generate profits from tourism activities and trading without paying the cost of maintenance and management of cultural heritage, while creating the external costs of congestion and environmental impact on the system.

The external effects of the presence of cultural heritage also determine the additional value appreciation of real estate. This added value can be estimated using hedonic pricing methods, expressing the value of the cultural factor in the overall real estate value of the asset. The estimated 
economic value can also be inferred by contingent evaluation methods such as willingness to pay or travel costs. These added values are sometimes seen as resources to be recovered at the local level In the Croatian context, according to the Law on the Protection and Preservation of Cultural Property, there is an existing heritage tax- "spomenička renta"-for all organizations, companies and individuals that produce goods or profit and are located in heritage areas (direct taxes on heritage), or for certain activities even if they are not located in the heritage areas (indirect asset tax). The fee is calculated based on the type of activity and size of the occupied area. At the moment there is no property tax-it is likely to be introduced during the year 2013.

\subsection{Public Participation}

Recent decades have witnessed the increasing involvement of different cultural and social groups, institutional cooperation between the different states and various international initiatives. The process of democratization of the cultural process brings new approaches to cultural creation and construction of heritage. The value itself is not univocal to these different individuals and groups and often there are explicit conflicts of values. The dialogue becomes the construction of shared values, a learning process, and the definition of the method for attempting to resolve conflicts.

It is of particular importance that public participation begins in the initial strategic phases. It is in these initial phases that the common objectives and values are defined and where new ideas to be tested can be sought out with an eye to creativity and collaboration. To this end the various processes and techniques of public participation may be of help and may involve small groups, but also the wider population (for example: six hats technique, future search, planning for real, choices method, partnership-led models, opinion polls, focus groups, referendum, citizen forums, citizen juries, deliberative surveys, citizen panels, e-forum and others...) [18-20]. These techniques may utilize specific models of evaluation and representation of (alternative) scenarios. These instruments can increase the transparency and rationality of discourse while clarifying the objectives and hidden interests, revealing the bases for new creative proposals of intervention on the landscape.

Therefore the role of evaluation in planning (in strategic and more advanced phases) is mainly to highlight possible conflicts and help resolve them during the formation of plans and projects (e.g., discussing the problems and trade-offs during the public discussions and meetings with different social sectors). The evaluation of alternatives can help to deduce social priorities on which to base new alternatives by creating positive-sum distributions, but remains an aiding tool in decision-making and not a substitute for it.

The decision-aid tools are part of the participatory processes that require strong democratic institutions and the development of an active citizenry [21,22] that perceives politics as a continuous evolutionary process. Deliberative democracy proposes citizen participation in public deliberation, according to the ideals of rational legislation, participatory politics and civic self-governance. For example, Jon Elster indicates that deliberation requires that citizens reorient from a self-centered and market-based view to one of public interest, and can have a positive impact only if it leads to better decisions. Elster also presents some objections, such as: even the organization of voluntary decisionmaking groups is not immune to the formation of élites that participate exclusively for their own interests and power; the possible clash of irreconcilable values; lack of time as the possible formation 
of the an accord as the mere aggregation of preferences; danger of different levels of acceptance of the accord; egoistic stance of the groups; acceptance due to mere conformism- the chameleon effect; egoistic agendas camouflaged as the reasoning for the common good [22,23].

In this view, the evaluations are founded on detailed descriptions of the impacts of the various alternatives, based on agreed-upon criteria and distribution over different sectors. Ideally, in evaluation dominant alternatives are sought in the iterative and interactive process, repeating this step with new information as it becomes available.

\section{Analysis and Evaluation Models for Heritage in Spatial Planning}

\subsection{Analysis and Evaluation Models in Spatial Planning}

Considering the characteristics of heritage and landscape, analysis and evaluation of heritage have to reflect the complexity of the types of heritage. Evaluations can have the objective of evaluation of externalities and of investment and management opportunities (both private and public), but can also indicate the problems and opportunities in the territory.

Tools for analysing complex spatial systems have to be suited to dealing with complexity, fragmentation, stratification and mutual relations between tangible and intangible spatial elements. The understanding of the area is not an end in itself, but aims at the reconstruction of the process of spatial transformation. Representation therefore has to reproduce the spatial complexity. The tools and methods required are no longer based only on knowledge of individual items but on knowledge of processes and monitoring systems and their relationships.

The values require qualitative and not merely monetary evaluation and their definition is necessary for the identification of economic and non-economic conflicts of interest of resource use. In the case of territories rich with heritage, such as landscape or urban heritage, analyses are carried out not only on the geological and biological components, but also on morphological and landscape characteristics. Adequate analyses are those such as historical-morphological transformation analysis of spatial characteristics, which has the purpose of avoiding the simplification of spatial representations.

Evaluations created as an aid to decision-making have to be able to confront the problems inherent in the decisional process: uncertainty of the data, different types and categories of data, variety of sources, difficulties in comparison, various objectives at play, presence of conflicts, hidden objectives, administrative time and others. In this perspective, a valid evaluation aids the procedural rationality and therefore the quality of the decision-making process, helps the production of new alternatives, stimulates the participation of various sectors and allows control during the execution phase (monitoring). Therefore, in view of a value-focused thinking [24], evaluations permit the identification of decision opportunities instead of searching for solutions to decision problems. Value orientation, besides helping the identification of new and desirable alternatives, also permits the clarification of hidden objectives, the identification of relevant indicators, more rational communication with non-technical groups and allows possible conflicts to be identified.

Evaluation models, being rational, logical and coherent, help in the management of complex qualitative, quantitative and often uncertain data, adapting to different contexts in the most transparent and simple manner possible. The management of physical systems, natural or built, cannot be considered separate from socio-cultural systems and the management process begins to integrate the 
multidisciplinary and public participation considerations (e.g., Strategic Environmental Assessment (SEA) [25]). In fact, as the multi-criterial evaluation is closely tied to Pareto efficiency [26], it follows that the evaluation of alternatives should broaden the knowledge of the proposals and create new alternatives. The alternatives should not only be evaluated against each other, but with the extant and the ideal point.

In planning, alternatives are expressed with the scenarios that represent the state of the territory in the possible future with long-term logic. The indicators that express the scenarios must express the spatial complexity, regarding identity and diversity, respect for the morphology and typology, public areas, perception of architecture, social and functional diversity, equilibrium between the role of public administration and private sector [27], and must reflect the social construction of values, because the sharing of values results in consideration and maintenance of heritage [28].

\subsection{The Implementation of the Models of Evaluation of Heritage}

The multi-criterial evaluation models integrate evaluations from different disciplinary fields. The modularity of the models allows the insertion of evaluations from the specific disciplines based on the evaluated context. Heritage contexts need methods and techniques specifically built for analysis and evaluation of cultural built and/or natural heritage, such as architectural and landscape heritage.

Methods for evaluation include specific analysis where the analytical and evaluative aspects are often difficult to separate. Models of evaluation of built heritage concentrate on a single object (or complex), while those of evaluation of the landscape take into account the landscape features but also all the relevant events contained in the landscape such as the buildings and gardens, engineering constructions, fences, trees and animals.

There are already different evaluation models used in planning and management situations such as: the matrix approach of Leopold [29], the creation of indications of the "pyramid of policies" [30], the evaluation of heritage of the Kalman method [31,32] or landscape evaluations [33,34], archaeological impact [35], integration of different techniques of analyses and articulation of Environmental Impact Assessment (EIA) [36], Strategic Environmental Assessment (SEA) and Community Impact Evaluation (CIE) [37]... The different methods are all useful in certain situations: some are more adequate for a first approach and analysis, others as detailed verification of a proposed option and others as a tool of representation and communication.

For example, some methods are constructed to manage basic data; other methods function only with very detailed data available. Some methods can manage both basic and detailed data, for example regarding a specific sub-objective or sector, depending on the use of the model. A brief overview of the characteristics of some of the most used evaluation models is given in Table 1. The best results are obtained by combining the different types of evaluation models, depending on the phase of the decision-making process, availability of data and specific objectives as communication or sectoral analysis. From the overview of the existing models it is also clear that there is a need for a model that could somehow respond to different moments of the land management process and still be directly oriented towards evaluation of heritage and its different aspects as well as the impacts of its transformation. 
Table 1. Overview of different evaluation models (+ stands for allows, $(+)$ for allows with specific regard).

\begin{tabular}{|c|c|c|c|c|c|c|c|c|c|c|}
\hline & 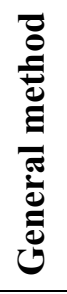 & 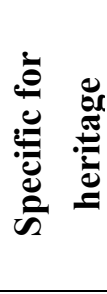 & 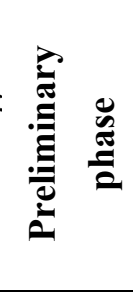 & D & 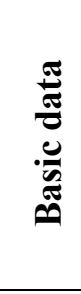 & 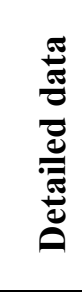 & 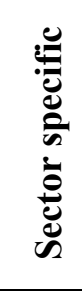 & 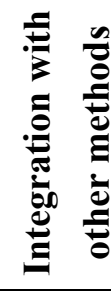 & 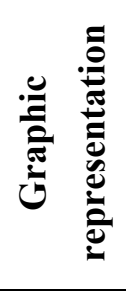 & 宽 \\
\hline SWOT analysis & + & & + & + & + & $(+)$ & $(+)$ & $(+)$ & & + \\
\hline Spider model & + & & + & + & + & $(+)$ & $(+)$ & $(+)$ & + & + \\
\hline Flag model & + & & $(+)$ & + & + & $(+)$ & $(+)$ & $(+)$ & + & + \\
\hline Economic-business model & + & & + & & + & & & $(+)$ & & + \\
\hline Pyramid model & & + & + & + & + & & & + & + & + \\
\hline Heritage value for money & & + & & + & $(+)$ & + & & + & $(+)$ & + \\
\hline EIA & + & & & + & & + & $(+)$ & + & & \\
\hline SEA & + & & & + & & + & $(+)$ & + & & \\
\hline CIE & + & & & + & $(+)$ & + & + & + & & + \\
\hline Kalman method & & + & + & + & + & $(+)$ & & $(+)$ & & + \\
\hline Landscape model & & + & + & + & + & $(+)$ & & $(+)$ & & + \\
\hline $\begin{array}{l}\text { Archaeological impact } \\
\text { model }\end{array}$ & & + & $(+)$ & + & + & & & $(+)$ & & \\
\hline
\end{tabular}

\subsection{The Models of Spatial Analysis}

To make evaluations we need data that we can obtain through spatial, landscape and heritage, economic, financial, social and institutional analysis. The analysis and definition of criteria and subcriteria, impacts and objectives of different social sectors and choice of the analysis methods are crucial for the development of a good heritage evaluation model as a decision-aid tool. The proposed interdisciplinary model can use multiple methods and techniques of analysis, such as operative sheets, panoramic optical cones, map-overlay, historical-spatial analysis... These techniques allow us to follow trends from past to future projections, highlighting the sustainability of the processes.

In this context, the techniques of morphological-historical analysis are very useful and can include: analysis of the dynamics of growth/urban transformation (e.g., Figure 1), dynamics of growth/process, dynamism of urban morphology and spatial analysis of urban land plots, both the built and of green and water (e.g., Figure 2), the analysis of relationships and transformations in sections and perspectives, and others. The analysis of urban texture and its interruptions is effective for identifying homogeneous urban areas, highlighting the extraordinary events and allowing the definition of actions based on specific spatial-morphologic units. In a similar way, the architectural complexes can be analysed by typological-functional analysis, structural system analysis, stratification analysis, construction phases identification, and others.

In the analysis of changes in the heritage and landscape, historical sources such as paintings, graphics, sculptures or photographs representing the territory are especially useful, particularly if effectuated from privileged points of the area, allowing their contemporary reconstruction as in optical cones. 
Figure 1. Development of urban texture (analysis based on the Austrian cadaster by Beck Pfilzner from 1819, Austrian cadaster by Joseph Eisner from 1879 and extant state).

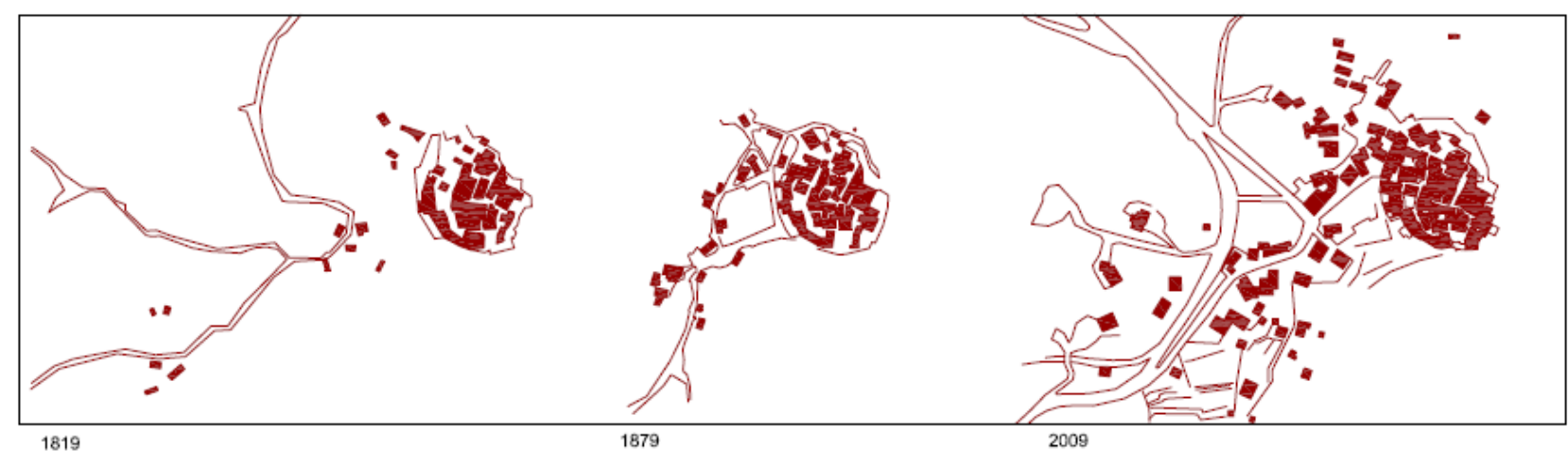

Figure 2. Characteristics of urban texture of Brseč.

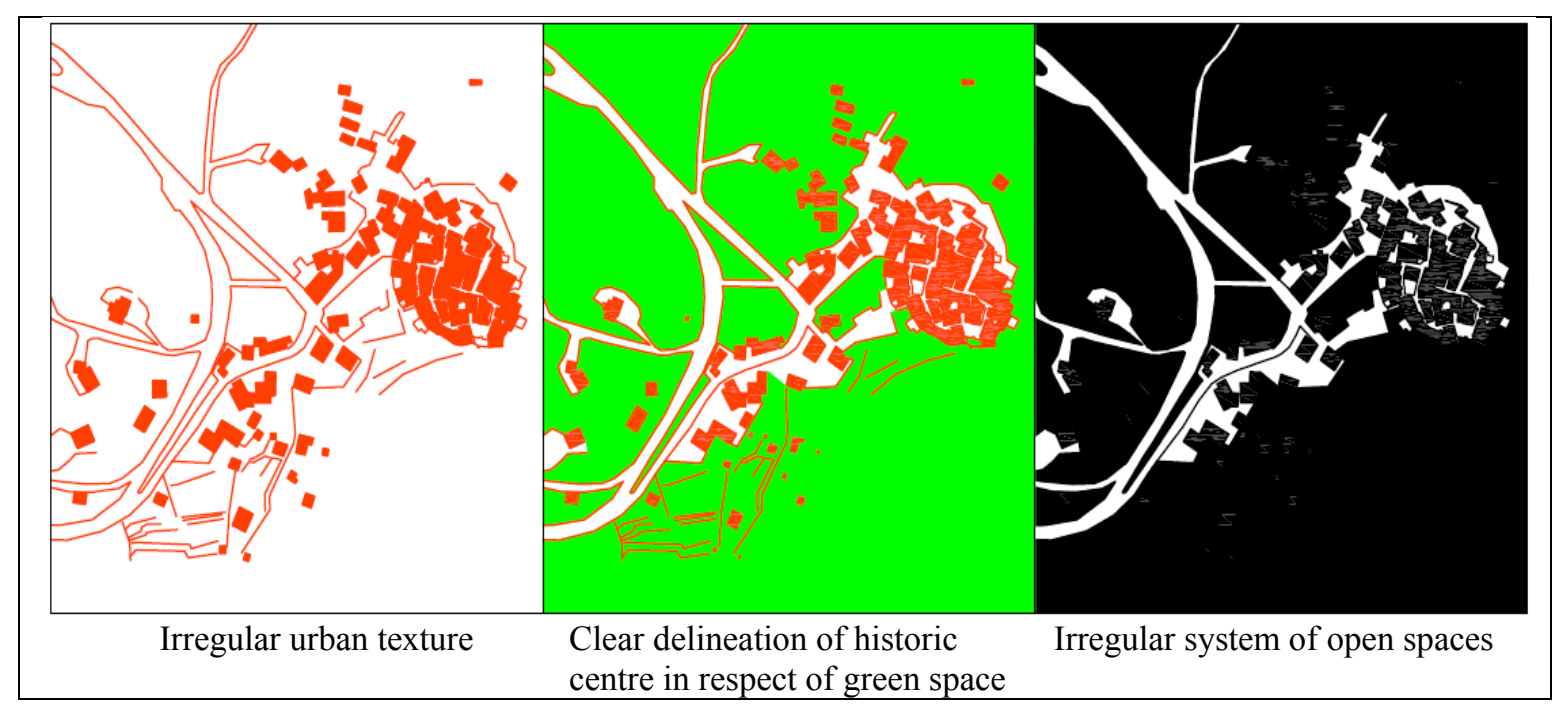

\subsection{The Proposal of the Decision-Aid Model for Heritage Management and Planning}

Based on the notions previously encountered, it was possible to create the evaluation model for the definition of management strategies for spatial heritage. The aim was to create a model that can be actually useable and rational, logical and coherent. The model also had to be able to handle real data — often from different sources, of different types and often uncertain or difficult to find. For this reason the constructed model is flexible (easily used with small adaptations in various contexts), modular (organized in thematic modules) and able to integrate with different techniques of thematic analysis.

Considering categories of similar heritage elements the model is articulated for different categories of the heritage (buildings and architectural complexes, urban sites, rural sites, archaeological and hydro-archaeological sites, ethnological sites, memorial sites, cultural landscapes), and therefore applicable to various heritage typologies (allowing for the flexibility of the model). The evaluation model is structured in modules (phases): (1) evaluation of heritage assets where the state and the management possibilities of the heritage are being evaluated; (2) definition of strategies - scenarios where one or more scenarios are proposed; and (3) the choice of actions to be performed (optional) where different scenarios are compared. 
At the core of the evaluation model are the Evaluation Matrices of the heritage (useable also for the assets that require verification of their heritage characteristics) based on the principles of Leopold's matrix model (and often used in EIA or SEA evaluations) and heritage evaluation of the Kalman method and landscape analysis. The evaluation matrices are defined for different categories of heritage and thematic modules related to the management of the heritage (characteristics of the context, historical and cultural characteristics of the heritage, intrinsic characteristics depending on the type of heritage, e.g., buildings, urban sites, rural sites..., fruition, functional and financial aspects, social aspects and pressures). In this way, if necessary, the specific modules, related to certain characteristics, can be easily extrapolated for easier comparison of different heritage assets or the comparison of the state of one heritage asset in different times.

The evaluation matrix contains themes (see above) organized in indicators and subindicators. The criteria are defined for each value of the subindicator allowing a transparent connection between the data and the value of the heritage for that indicator. During the research, the significant evaluation indicators were chosen upon the analysis of possible evaluation themes and issues for the heritage (Tables 2-4). It was important to represent the impacts on all social sectors and the environment. This part of the model could be further refined by collaboration of experts in different fields or through participatory procedures (e.g., juries, focus groups, e-forums, surveys... or a combination of different participatory options). The participation of a wider public would be particularly interesting in defining additional indicators and especially the weights (e.g., through surveys with open-ended questions or 'ranking' questions). Although today it is easier than ever, the organisation of public or expert participation is directly connected to the political will to include the experts and public in strategic decisions.

In the matrices, the indicators and criteria are connected to the guidelines for interventions on the heritage - interventions of conservation and actions needed to manage the assets in the view of sustainable and durable development. Therefore it is possible to read the guidelines for the intervention that correspond to the described state of the heritage. This is one possible way to define the strategies of intervention. Those strategies can be comprehensive or partial, e.g., specific goals (it is necessary to verify the condition of urgency first).

Another, easier for the user, way of defining the comprehensive strategies for the heritage element is the placement of the heritage within the "triangle of the strategies" (developed on the basis of the "pyramid of policies" created by Giovanni Campeol as a part of his research on environmental evaluation at Università IUAV, Venezia, Italy [30]) illustrated in Figure 3. Depending on the location within the fields of the graph, indications are given on strategic actions to be carried out on the heritage for the optimal management of the good. Those indications are outlined in the tables apart (an abstract of which is given in Table 7), connected to the fields of the graph and could be the basis for the development of an information technology platform. The indications cover all evaluated characteristics, actions on the context and on the good itself: acts of physical intervention on the good, actions to improve use, management and social inclusion. The "triangle of strategies" is built according to the instructions contained in the evaluation matrix, separately for each class of heritage good, adapted to the characteristics of the good, both in the range of scores and in adequacy with the indications given in matrices. 
Table 2. An abstract of analysis of evaluation indicators (the complete analysis is contained in the unpublished material of the doctorate thesis of the author [38]).

\begin{tabular}{|c|c|c|c|}
\hline $\begin{array}{l}\text { Group of } \\
\text { Indicators }\end{array}$ & Indicators & $\begin{array}{l}\text { Group of } \\
\text { Indicators }\end{array}$ & Indicators \\
\hline $\begin{array}{l}\text { Natural } \\
\text { geological }\end{array}$ & $\begin{array}{l}\text { Hydro-geological risk } \\
\text { Protection of water } \\
\text { Geological diversity } \\
\text { Morphological diversity }\end{array}$ & $\begin{array}{l}\text { Natural } \\
\text { environmental }\end{array}$ & $\begin{array}{l}\text { Biological diversity and/or } \\
\text { biological uniqueness } \\
\text { Presence of nature continuity } \\
\text { Panoramic views } \\
\text { Size and quality of green areas } \\
\text { Air quality/noise/traffic }\end{array}$ \\
\hline $\begin{array}{l}\text { Formal } \\
\text { (urban/arch } \\
\text { itectural) } \\
\text { and } \\
\text { historical }\end{array}$ & $\begin{array}{l}\text { Representativeness of the historical period } \\
\text { Representativeness of urban typology } \\
\text { Antiquity } \\
\text { Degree of transformation } \\
\text { Degradation of the physical material } \\
\text { Architectural and artistic character recognition } \\
\text { Recognition of spatial relations } \\
\text { Cultural diversity and/or uniqueness of heritage } \\
\text { Elements of organisation of production space } \\
\text { Elements of material and technological culture } \\
\text { of territory infrastructure }\end{array}$ & $\begin{array}{l}\text { Cultural } \\
\text { function }\end{array}$ & $\begin{array}{l}\text { Presence of cultural goods } \\
\text { Related artistic production } \\
\text { Improved knowledge of } \\
\text { information } \\
\text { on the area } \\
\text { Role in primary, secondary and } \\
\text { specialized education } \\
\text { Research (techniques, history of } \\
\text { art and architecture, history, } \\
\text { sociology, production...) } \\
\text { Archives (technology, society, } \\
\text { environment...) } \\
\text { Local specific production } \\
\text { Use of particular construction } \\
\text { technologies } \\
\text { Use of materials }\end{array}$ \\
\hline $\begin{array}{l}\text { Spatial } \\
\text { function }\end{array}$ & $\begin{array}{l}\text { Compatibility with contemporary uses } \\
\text { Communication outside area } \\
\text { Reduction of open space fragmentation } \\
\text { Areas of open public space } \\
\text { Areas of closed public space } \\
\text { Use of renewable energy sources } \\
\text { Pedestrian and cycling communications } \\
\text { Energy efficiency } \\
\text { Efficient waste management }\end{array}$ & Social & $\begin{array}{l}\text { Perception of value by residents, } \\
\text { tourists and interest groups } \\
\text { (groups of heritage protection, } \\
\text { artists, economy actors...) } \\
\text { Perception of identity by residents } \\
\text { Presence of conflicts of interest } \\
\text { Perception of self } \\
\text { Social networking between local } \\
\text { and/or external interest groups }\end{array}$ \\
\hline $\begin{array}{l}\text { Economic } \\
\text { and } \\
\text { financial }\end{array}$ & $\begin{array}{l}\text { Usable built areas of low/medium/high degradation } \\
\text { Area suitable for income activities } \\
\text { Area suitable for subsidized } \\
\text { activities/community and/or public interest } \\
\text { Cost/benefits in the short/medium/long term } \\
\text { Definition of property rights } \\
\text { Sustainability markers }\end{array}$ & Institutional & $\begin{array}{l}\text { Collaboration: public-public } \\
\text { Collaboration: public-private } \\
\text { Collaboration: international } \\
\text { Clarity of the law } \\
\text { Speed of practice } \\
\text { Transparent processes }\end{array}$ \\
\hline
\end{tabular}


Table 3. An abstract of analysis of evaluation indicators (the complete analysis is contained in the unpublished material of the doctorate thesis of the author [39]).

\begin{tabular}{|c|c|c|c|}
\hline Group of Indicators & Indicators & & Sectors \\
\hline \multirow{3}{*}{$\begin{array}{l}\text { Natural } \\
\text { environmental }\end{array}$} & $\begin{array}{l}\text { relationship } \\
\text { natural/built areas }\end{array}$ & $\mathrm{m}^{2} / \mathrm{m}^{2} ; \mathrm{m}^{2} / \mathrm{m}^{3}$ & $\begin{array}{l}\text { public, residents in the area, residents } \\
\text { neighbouring areas, tourism }\end{array}$ \\
\hline & panoramas & $\begin{array}{l}\% \text { in optical } \\
\text { cone }\end{array}$ & $\begin{array}{l}\text { private, public, residents in the area, residents } \\
\text { neighbouring areas, tourism }\end{array}$ \\
\hline & $\begin{array}{l}\text { relationship } \\
\text { natural/built areas }\end{array}$ & $\mathrm{m}^{2} / \mathrm{m}^{2} ; \mathrm{m}^{2} / \mathrm{m}^{3}$ & $\begin{array}{l}\text { public, residents in the area, residents } \\
\text { neighbouring areas, tourism }\end{array}$ \\
\hline \multirow{2}{*}{$\begin{array}{l}\text { Formal } \\
\text { (urban/architectural) } \\
\text { and historical } \\
\text { characteristics }\end{array}$} & $\begin{array}{l}\text { representativeness of } \\
\text { the historical period }\end{array}$ & experts & public, tourism \\
\hline & $\begin{array}{l}\text { degree of } \\
\text { transformation }\end{array}$ & experts & private, public, residents in the area, tourism \\
\hline \multirow{3}{*}{ Economic } & useable built areas & $\mathrm{m}^{2}$ & private, public \\
\hline & sustainability markers & experts & $\begin{array}{l}\text { public, residents in the area, residents } \\
\text { neighbouring areas }\end{array}$ \\
\hline & tourist value & $\begin{array}{l}\text { experts, } \\
\text { surveys... }\end{array}$ & $\begin{array}{l}\text { private, public, residents in the area, residents } \\
\text { neighbouring areas, tourism }\end{array}$ \\
\hline \multirow[t]{2}{*}{ Social } & $\begin{array}{l}\text { perception of value by } \\
\text { residents and/or } \\
\text { interest groups }\end{array}$ & experts, surveys & $\begin{array}{l}\text { private, public, residents in the area, residents } \\
\text { neighbouring areas, tourism }\end{array}$ \\
\hline & $\begin{array}{l}\text { perception of identity } \\
\text { by residents }\end{array}$ & experts, surveys & public, residents in the area \\
\hline \multirow{2}{*}{ Institutional } & $\begin{array}{l}\text { public-private } \\
\text { partnership }\end{array}$ & experts & $\begin{array}{l}\text { private, public, residents in the area, residents } \\
\text { neighbouring areas, tourism }\end{array}$ \\
\hline & speed of practice & experts & $\begin{array}{l}\text { private, public, residents in the area, residents } \\
\text { neighbouring areas, tourism }\end{array}$ \\
\hline
\end{tabular}

Table 4. An abstract from the analysis of economic and financial sustainability indicators (the complete analysis is contained in the unpublished material of the doctorate thesis of the author [40]).

\begin{tabular}{|c|c|c|c|}
\hline \multirow{3}{*}{$\begin{array}{l}\text { Operations of } \\
\text { conservation and } \\
\text { requalification }\end{array}$} & $\begin{array}{l}\text { Costs of environmental } \\
\text { requalification }\end{array}$ & \multirow{3}{*}{ Excavation costs } & $\begin{array}{l}\text { Organisation and protection } \\
\text { works }\end{array}$ \\
\hline & Construction work costs & & Excavation works \\
\hline & New agricultural assets cost & & Conservation of the findings \\
\hline \multirow{2}{*}{$\begin{array}{l}\text { Management- } \\
\text { related costs }\end{array}$} & $\begin{array}{l}\text { Salaries and other } \\
\text { staff-related costs }\end{array}$ & \multirow{2}{*}{$\begin{array}{l}\text { Costs of } \\
\text { subventions }\end{array}$} & Direct subventions to private \\
\hline & $\begin{array}{l}\text { General annual maintenance } \\
\text { costs mean for } 10 \text { years }\end{array}$ & & $\begin{array}{l}\text { Indirect subventions (tax and } \\
\text { loan subventions) to private }\end{array}$ \\
\hline \multirow[b]{2}{*}{$\begin{array}{l}\text { Production-related } \\
\text { costs }\end{array}$} & Fixed assets maintenance & \multirow[b]{2}{*}{$\begin{array}{l}\text { Direct income } \\
\text { (public) }\end{array}$} & Localization and heritage tax \\
\hline & $\begin{array}{l}\text { Costs of material not produced } \\
\text { on site }\end{array}$ & & $\begin{array}{l}\text { Taxes on revenues from } \\
\text { spending } \\
\text { in situ }\end{array}$ \\
\hline
\end{tabular}


Table 4. Cont.

\begin{tabular}{|c|c|c|c|}
\hline \multirow{2}{*}{ General costs } & Contingency allowance & \multirow{13}{*}{$\begin{array}{l}\text { Sustainability } \\
\text { markers }\end{array}$} & Number of people employed \\
\hline & Finance costs & & New businesses \\
\hline \multirow{6}{*}{ Earned income } & \multirow{2}{*}{ Revenues from spending in situ } & & New population attracted \\
\hline & & & Income levels of residents \\
\hline & Number of overnight stays & & \multirow{2}{*}{$\begin{array}{l}\text { Ratio income received by the } \\
20 \% \text { highest and lowest } \\
\text { earning }\end{array}$} \\
\hline & Revenue from renting & & \\
\hline & Biodiversity prospecting & & $\begin{array}{l}\text { Gender structure of labour } \\
\text { force }\end{array}$ \\
\hline & Products sold & & Number of operators \\
\hline Contributed income & Donations & & $\begin{array}{l}\text { Sale of products carrying } \\
\text { registered product names }\end{array}$ \\
\hline General income & Development rights transfer & & $\begin{array}{l}\text { Share of assisted investments } \\
\text { aiming to improve biodiversity }\end{array}$ \\
\hline & Net precent yolue & & Share of assisted \\
\hline Viability & Net present value & & investments aiming to \\
\hline & Payback period & & improve animal welfare \\
\hline
\end{tabular}

Figure 3. The principle of organization of the "triangle of the strategies" where the heritage is positioned in one of the fields based on positive and negative characteristics. Every field is connected to the table with the indications for the valorisation of the heritage.

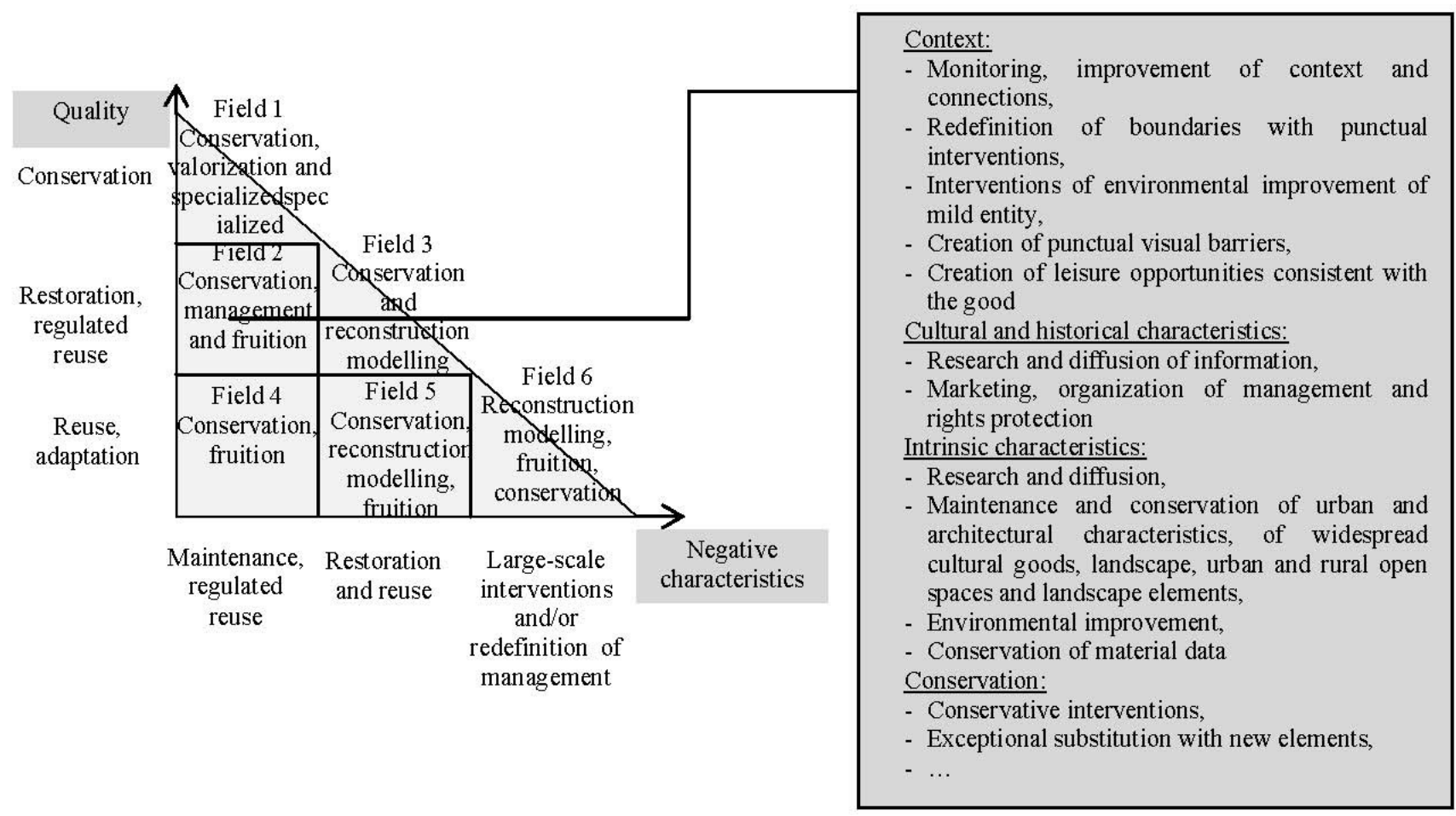

In the third part, the different scenarios for the same heritage asset can be compared among them, or scenarios of interventions on different assets can also be compared in the same manner. This part can be obtained by reapplying the evaluation matrices or through the use of a different prioritization 
method (Community Impact Evaluation CIE (Lichfield), Analytic Hierarchy Process (AHP), Analytic Network Process (ANP) by Saaty, theory of Zeleny, analysis of Regime by Nijkamp and Hinloopen [41], Evamix method, Vimda method, software DEFINITE [42] and others), or both. The results could be the bases for public discussion about strategies to implement through urban and strategic plans.

The analysed and evaluated heritage property can be synthetically represented with the Synthetic Card for easier communication and consultation. It is proposed that the evaluation model could be integrated with information technologies and databases for easier access, consultation, inquiries, update and communication with the public (including feedback from the field and integration with mobile applications).

The strategic application of the evaluation model would comprise comparison of different sites and different management options for the sites in question. The different scenarios could be discussed and the optimal scenarios chosen. In the case of the evaluation of the single site, different scenarios could be evaluated for a single site, where the financial analysis would have to be of foremost importance.

The proposed model could be the basis for the development of additional models, capable of evolving, integrating technological innovations in the collection, management and reporting of data.

\section{Application of the Evaluation Model to a Case Study: Urban Site of Brseč (Croatia)}

\subsection{Urban Site of Brseč - an Abstract of the Evaluation of the Site}

The urban site of Brseč, Croatia, is located near the sea on the eastern coast of the Istrian peninsula and is a part of the administrative unit of the City of Mošćenička Draga in the county of Primorsko-goranska. The site extends to the urban centre of the town and the area outside the walls, for the surface area of 9 hectares. Brseč is located halfway between two important touristic centres (the Habsburg touristic centre at Opatija and the Roman plant city Pula). The coastal areas of Croatia are highly touristic areas, with mostly recent and often disorganized constructions of "sleeping zones" active only in summer, seaside activities and small historic centres (such as Brseč) that attract brief excursions and sightseeing. The Istrian peninsula is the most developed region in Croatia, with strong tourism, and agricultural, industrial and cultural production. The analysed urban site ranges out to $0.0892 \mathrm{~km}^{2}$ with 131 inhabitants. The main activity is tourism [43].

Brseč is located in the coastal zone at $157 \mathrm{~m}$ a.s.l. The town of Brseč is strategically located almost directly above the sea due to the need for protection during different historical periods, and dominates its cultural landscape. It has a rich history that makes it a part of important central European historic relations. The historical records first mention Brseč in 1102 when castrum Brisantina passed to the Patriarch of Aquileia by way of the Weimar-Orlamünde family. How and when this town passed from the Croatian government (to which it belonged, according to Byzantine sources) to the German one is still the subject of scientific debate. From the patriarchs of Aquileia, Brseč passed to the counts of Duino, then by hereditary lines to the counts von Walsee and in 1466 to Habsburg. In the 17th century this town for a short time passed to the Venetian government, and then proceeded to the Austrian government. In 1918 the territory of Brsešcina passed to the Kingdom of Italy and from 1945 to Yugoslavia and then Croatia.

The urban settlement grows on an ancient and prehistoric settlement, with traces of prehistoric fortifications incorporated into the structure of the modern town [44]. Most obvious are the medieval 
city walls and castle. During the 17 th or 18 th century the fortification system was consolidated and strengthened, and residences were built along the walls, always of a defensive character. The buildings are prevalently of the baroque style. From the 19th century the town expanded outside the walls (north, north-west, south) [45].

The urban site of the settlement of Brseč is a cultural good registered in the Register of Cultural Heritage in the Republic of Croatia, but the site contains many other registered properties (such as: the ethnological good of Toš (mill for olives), the home of Eugen Kumičić (political writer) and the site of a battle in World War II). Other important assets are the town gateway with the lodge (Figure 4) the remains of city walls and towers, and the Manšunerija building. Brseč is part of the Glagolitic alphabet extension, visible in some epigraphic fragments in Glagolitic alphabet (the oldest from 1561) and Latin [45] (Figure 5). In the town there are also some active cultural and sports organizations [43]. The most important heritage property is the Romanesque church of St. Juraj (St. George) at the centre of Brseč, which was enlarged in the 17th century (Figure 6). The church is dedicated to St. George and related to typical elements of the landscape previously devoted to Slavic mythology. The tower was also used in defence of the city [46]. The proximity of the town is also rich with important cultural and natural heritage (such as: remains of different churches, the archaeological remains of St. Margareta church and a traditional manufacturing complex, the remains of the ancient citadel Gradac, the late ancient and Byzantine ruins with the remains of the Church of St. John, the prehistoric checkpoint, the semi-cavern Provrtenica and many others [44]). The urban site is not in need of urgent intervention.

Figure 4. The city gate with the lodge and the building near the city lodge.

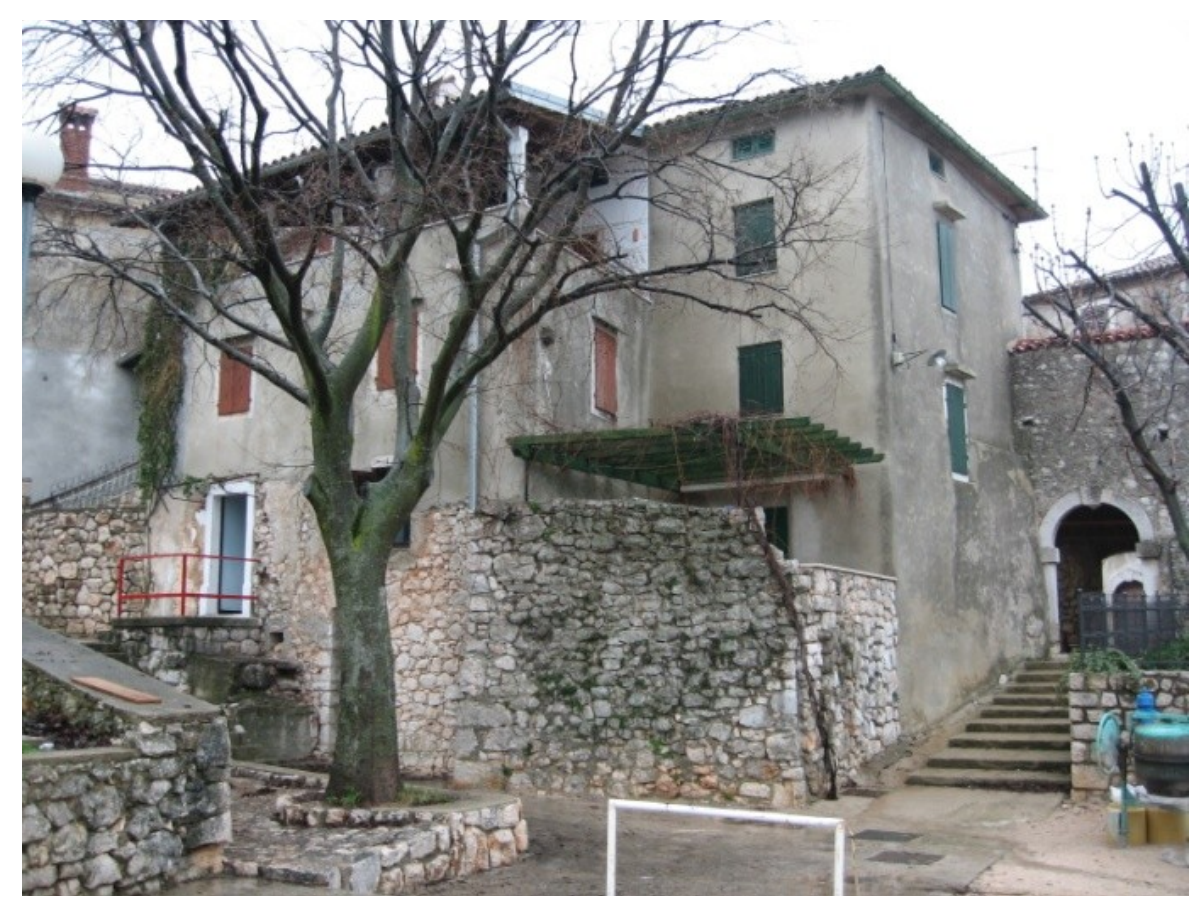


Figure 5. Epigraphy writing, often a part of building facades.

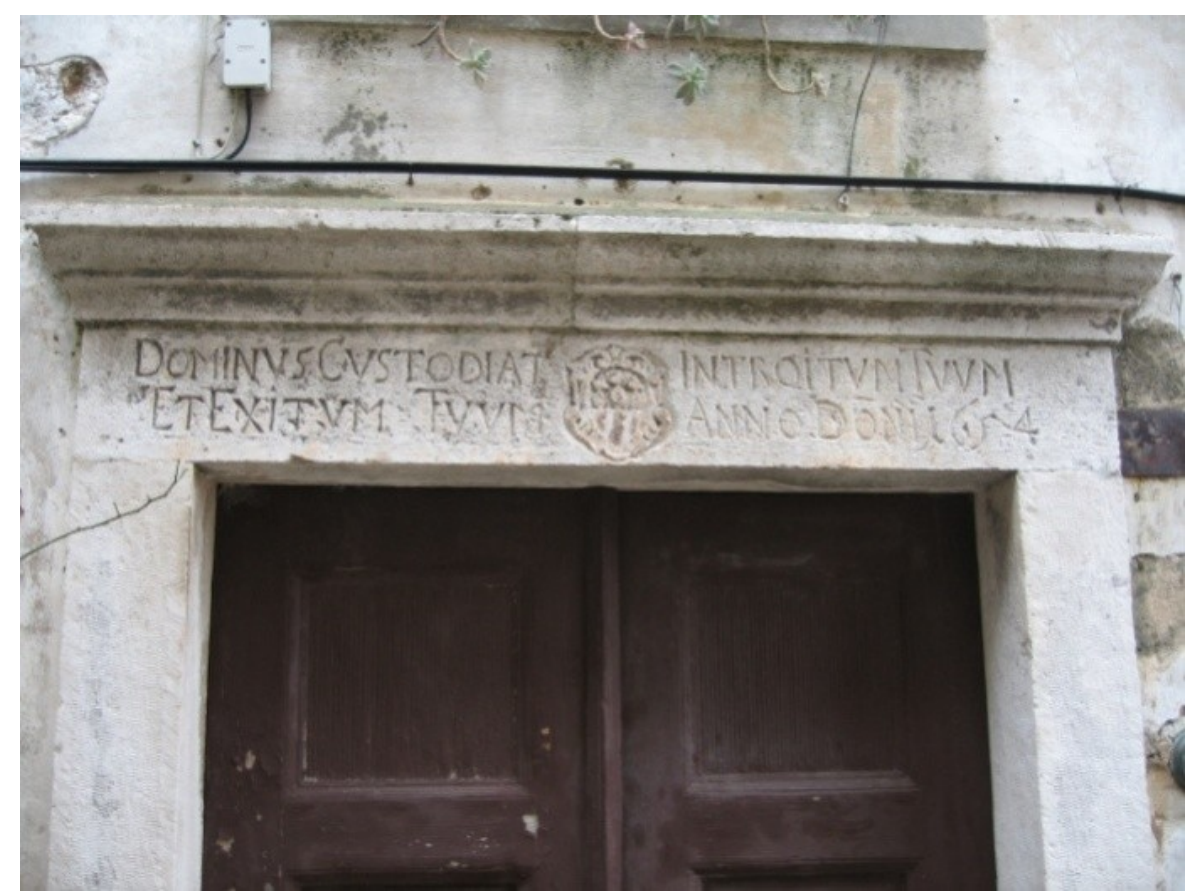

Figure 6. A view of the city tower.

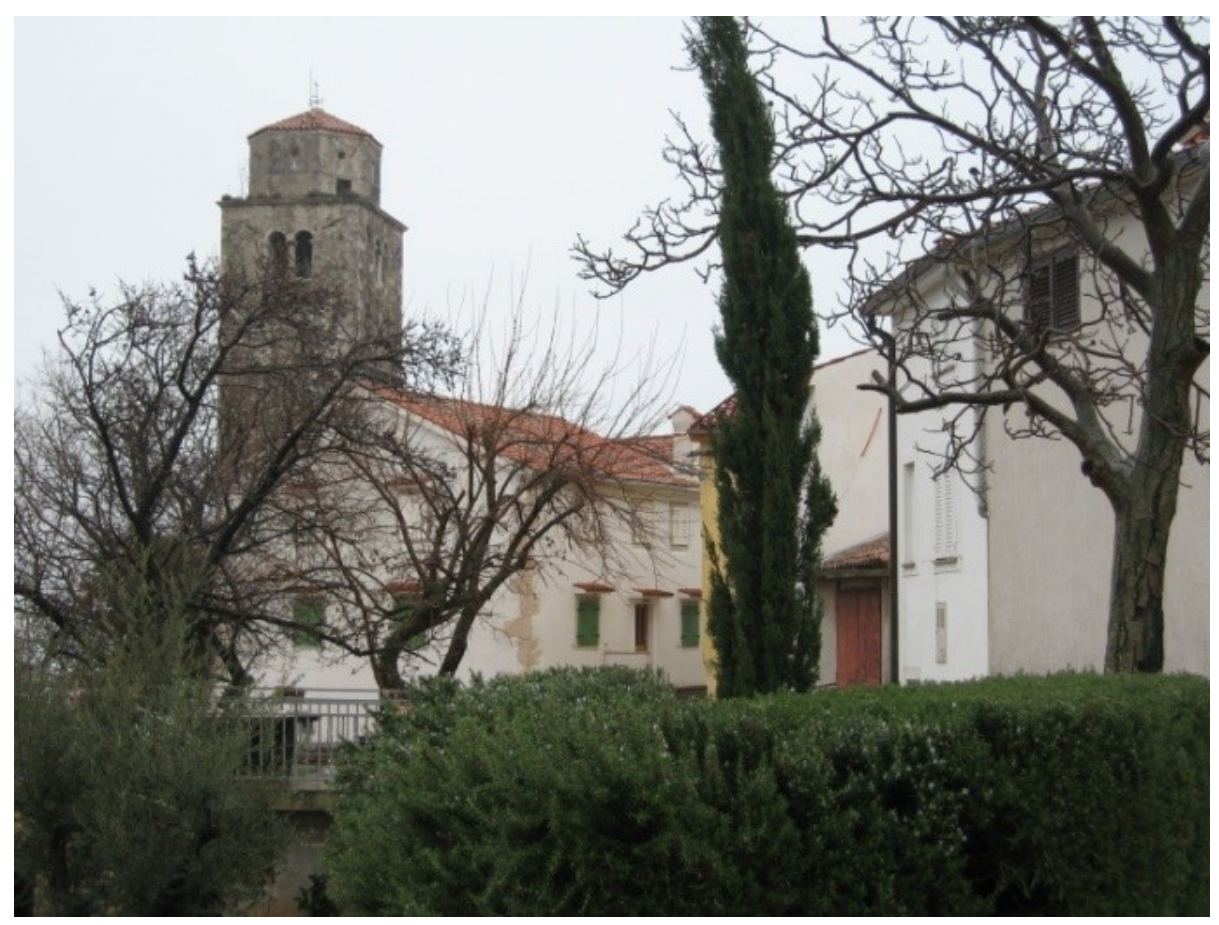

A part of the Brsešcina landscape is located within the Učka Nature Park. The areas near the urban centre are characterized by karst phenomena such as the presence of ponds, one near the entrance of the town. The urban centre is surrounded by wooded vegetation, and prevalently sub-Mediterranean caduceus. Particularly important and increasingly rare are sub-Mediterranean dry grasslands rich in biodiversity such as e.g., the endemic species Dianthus sanguineus (more detailed analysis is contained in the planning documentation [43] and the author's thesis [44]). The protection of the coastal zone is proposed, especially in the area under Brseč and corresponding underwater area. 
The Republic of Croatia is territorially organized into counties, which are divided into municipalities or cities. Each of these local self-government levels cover all institutional aspects inside of their land limits but are subordinated to the central government and ministerial directions. The State has decisive power on matters of a local level, both through direct intervention (e.g., the Conservation office of the Ministry of Culture) and by approving the plans produced by the local level government. For example, the local government can decide to protect a heritage element, but the power of registration is given to the Conservation office. This organisation often leads to different positions of local and central government but also to a lack of coverage of certain issues due to the uncoordinated action of the different governmental bodies. In the case of the heritage-where the interest of ministries of culture, of tourism, economy and finance, land organisation, environmental protection, education, transports, rural development.... often overlap — the process of land planning can be a point of encounter and rational construction of choices. The land planning process is today the only process where public participation is legally prescribed, thereby making it an important opportunity to transform the collecting of opinions of governing bodies into active coordination and openness to public interests through constructive dialogue.

Upon the analysis of the characteristics of the urban site and its context (just briefly illustrated above), mostly based on interdisciplinary data prepared for land planning analysis, literature and the analysis of spatial characteristics, the evaluation of the site proceeded using the evaluation matrix of the proposed multi-criteria model (described in the previous chapter). An abstract of the matrix is given in Table 5. It can be seen that the characteristics of the site are divided into themes or modules (Physical-geographical characteristics of the context, Cultural and historical characteristics, Intrinsic characteristics of the good-urban and architectural characteristics, State of conservation, Fruition characteristics, Finance and management, Social characteristics, Threats and pressures). Each of these thematic modules are organized in indicators, subindicators and descriptive criteria (first three columns). To each criterion corresponds a possible value, which can be assigned in column four. The fifth column gives the guidelines for intervention that correspond to the described state of the heritage. The last two columns give the weight and the weighted score of the evaluated characteristic. With the use of the model by the interdisciplinary commission, the criteria and weight could be further adjusted. At the end, the positive and negative scores can be summarized for a module and for the complete matrix (Table 6-the themes with mostly negative characteristics are marked in grey). 
Table 5. An abstract from the evaluation matrix for the urban site of Brseč (the complete matrices are contained in [47]).

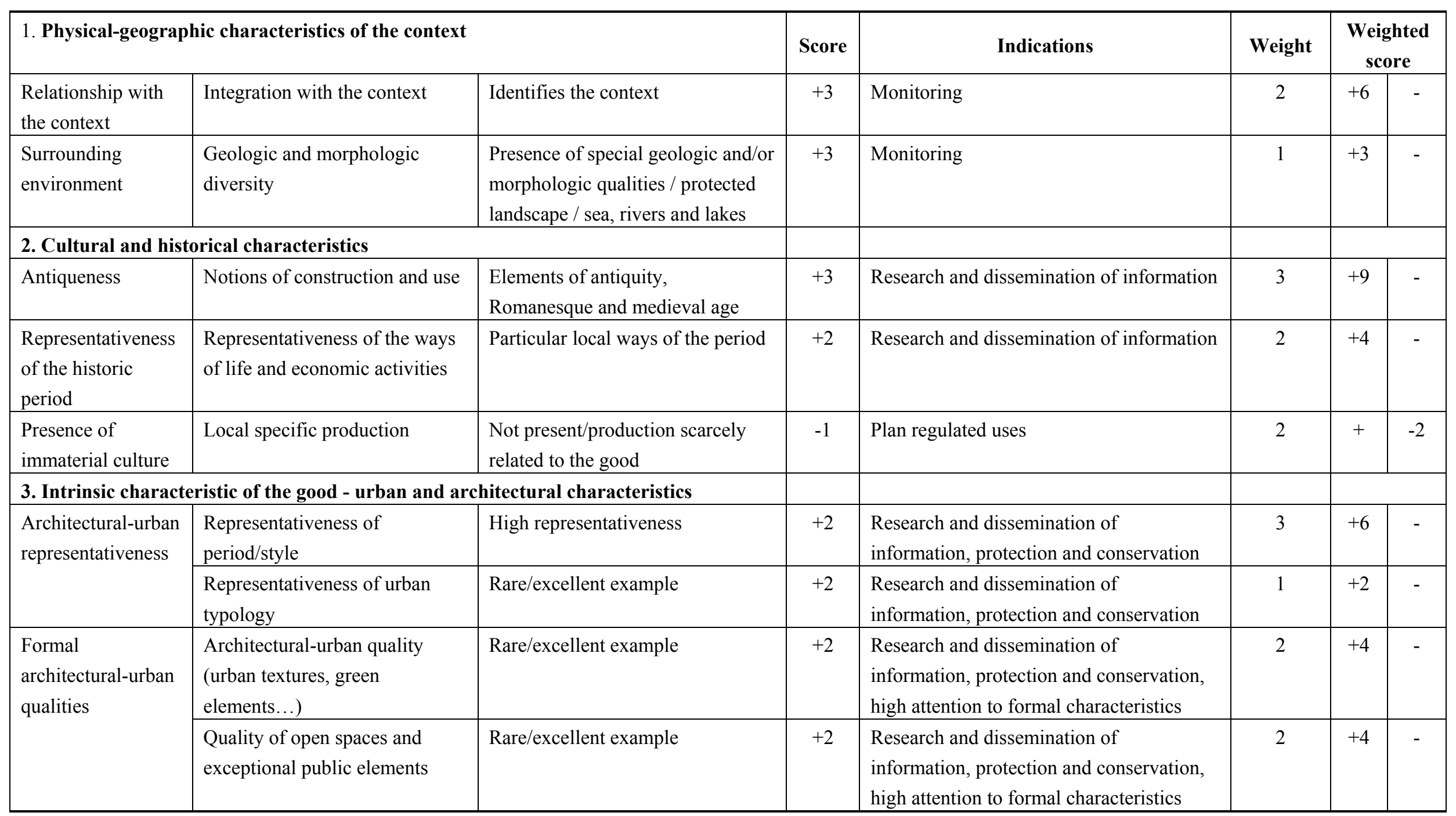


Table 5. Cont.

\begin{tabular}{|c|c|c|c|c|c|c|c|}
\hline \multicolumn{3}{|c|}{ 4. State of conservation } & \multirow{2}{*}{$\begin{array}{l}\text { Score } \\
+2\end{array}$} & \multirow{2}{*}{$\begin{array}{l}\text { Indications } \\
\text { Research and dissemination of } \\
\text { information, protection and conservation, } \\
\text { high attention to formal characteristics }\end{array}$} & \multirow{2}{*}{$\begin{array}{c}\text { Weight } \\
2\end{array}$} & \multicolumn{2}{|c|}{$\begin{array}{c}\text { Weighted } \\
\text { score }\end{array}$} \\
\hline $\begin{array}{l}\text { Degree of } \\
\text { transformation }\end{array}$ & $\begin{array}{l}\text { Recognition of spatial relations } \\
\text { (hierarchy of spaces and } \\
\text { buildings) }\end{array}$ & Rare/excellent example & & & & +4 & - \\
\hline $\begin{array}{l}\text { Physical state of } \\
\text { the material }\end{array}$ & $\begin{array}{l}\text { Degradation of the physical } \\
\text { material of construction }\end{array}$ & Good state & +2 & $\begin{array}{l}\text { Regulated maintenance and conservation } \\
\text { of construction elements }\end{array}$ & 1 & +2 & - \\
\hline \multicolumn{8}{|c|}{ 5. Fruition characteristics } \\
\hline \multirow[t]{2}{*}{ Accessibility } & Proximity of connections & $\begin{array}{l}\text { Accessible mostly by private } \\
\text { transport }\end{array}$ & -1 & $\begin{array}{l}\text { Interventions of improvement of public } \\
\text { services }\end{array}$ & 3 & + & -3 \\
\hline & Fruition & Lack of services & -2 & $\begin{array}{l}\text { Creation of fruition related services and } \\
\text { specialized management organizations }\end{array}$ & 3 & + & -6 \\
\hline $\begin{array}{l}\text { Fruition in } \\
\text { cooperation }\end{array}$ & $\begin{array}{l}\text { Fruition in cooperation with } \\
\text { other patrimonial sites in } \\
\text { proximity }\end{array}$ & Lack of network fruition & -3 & $\begin{array}{l}\text { Organisation and network association, } \\
\text { coordinated management organisations, } \\
\text { information and management services }\end{array}$ & 1 & + & -3 \\
\hline \multicolumn{8}{|c|}{ 6.Finance and management } \\
\hline \multirow[t]{2}{*}{$\begin{array}{l}\text { Management } \\
\text { aspects }\end{array}$} & $\begin{array}{l}\text { Area suitable for income } \\
\text { generating activities }\end{array}$ & More than 20\% & +1 & Monitoring & 3 & +3 & - \\
\hline & $\begin{array}{l}\text { Area suitable for subsidized } \\
\text { activities of collective interest }\end{array}$ & More than $20 \%$ & +1 & Monitoring & 3 & +3 & - \\
\hline $\begin{array}{l}\text { Presence of } \\
\text { financial funds }\end{array}$ & International funds & Not used for administrative reasons & -3 & $\begin{array}{l}\text { Improving administrative capacity and } \\
\text { hiring of consultants }\end{array}$ & 3 & + & -9 \\
\hline \multirow{2}{*}{$\begin{array}{l}\text { Tourism and } \\
\text { commercial } \\
\text { activities }\end{array}$} & Public interest & International & +3 & Information and marketing & 3 & +9 & - \\
\hline & Site extension & $\begin{array}{l}\text { Site physically identifiable on } \\
\text { urban scale }\end{array}$ & +2 & Information and marketing & 3 & +6 & - \\
\hline
\end{tabular}


Table 5. Cont.

\begin{tabular}{|c|c|c|c|c|c|c|c|}
\hline \multicolumn{3}{|c|}{ 7. Social characteristics } & \multirow{2}{*}{$\begin{array}{c}\text { Score } \\
-1\end{array}$} & \multirow{2}{*}{$\begin{array}{l}\text { Indications } \\
\qquad \begin{array}{l}\text { Modification of management principles, } \\
\text { creation of opportunities for participation } \\
\text { in activities, membership }\end{array}\end{array}$} & \multirow{2}{*}{$\begin{array}{c}\text { Weight } \\
2\end{array}$} & \multicolumn{2}{|c|}{$\begin{array}{l}\text { Weighted } \\
\text { score }\end{array}$} \\
\hline $\begin{array}{l}\text { Potential of } \\
\text { participation }\end{array}$ & Management & $\begin{array}{l}\text { Lack of activities oriented to local } \\
\text { public, associations and friends }\end{array}$ & & & & + & -2 \\
\hline & Creation of social networks & Lack of social networks & -1 & $\begin{array}{l}\text { Creation of social, institutional networks, } \\
\text { organisations of population and interest } \\
\text { groups }\end{array}$ & 1 & + & -1 \\
\hline \multicolumn{8}{|c|}{ 8. Threats and pressures } \\
\hline $\begin{array}{l}\text { Natural } \\
\text { environment }\end{array}$ & $\begin{array}{l}\text { Hydrogeological risk (floods, } \\
\text { landslides...) }\end{array}$ & High hydrogeological risk & -3 & $\begin{array}{l}\text { Interventions to guarantee safety of } \\
\text { significant entity }\end{array}$ & 3 & - & -9 \\
\hline State of the good & State of urgency & No & -3 & Urgent interventions & 3 & - & - \\
\hline
\end{tabular}

Table 6. Total score of the Urban site of Brseč analysis after the evaluation of the site, for different thematic categories and total score.

\begin{tabular}{cccc}
\hline Thematic category: & Quality score & Degradation score & Total score \\
\hline Physical-geographic characteristics of the context: & $+28 / 33$ & $/ 33$ & $+28 / 33$ \\
Historical and cultural characteristics: & $+27 / 39$ & $/ 12$ & $+27 / 39$ \\
Intrinsic characteristic of the good-urban and & $+30 / 57$ & $/ 30$ & $+30 / 57$ \\
architectural characteristics: & & & \\
State of conservation: & $+18 / 27$ & $/ 27$ & $+18 / 27$ \\
Fruition characteristics: & $+6 / 27$ & $-12 / 27$ & $-6 / 27$ \\
Finance and management aspects: & $+32 / 105$ & $-24 / 105$ & $+8 / 105$ \\
Social characteristics: & $+8 / 33$ & $-3 / 33$ & $+5 / 33$ \\
Threats and pressures: & $/ 0$ & $-22 / 48$ & $-22 / 48$ \\
Score & $+149 / 321$ & $-61 / 315$ & $+88 / 369$ \\
\hline
\end{tabular}


The compilation of the evaluation matrix, in the described manner, gives us the scores for thematic modules and total scores of positive and negative characteristics of the analysed site (Table 6). From this score we can see that the strong points of the urban site of Brseč are: the Physical-geographical characteristics of the context (or rather the cultural heritage, geomorphologic and natural quality of the landscape of Brsešćina), the Historical and cultural characteristics (Connection to important events in international history, Urban and regional characteristics, especially the Representativeness of the period/style of the urban typology, and the Presence of cultural goods) and the State of conservation which can be judged as relatively good.

The critical points are: Fruition characteristics (difficult to approach without private means, lack of information services or services for people with reduced mobility, lack of cooperation with other heritage sites in the vicinity), Finance and Management aspects (lack of planned activities), the Social characteristics (lack of activities including the public and social networks), Threats and pressures (hydrological risks).

\subsection{Evaluation of Scenarios-Case of the Choice of Investment}

After the evaluation of the characteristics of the urban site it is possible to create different scenarios using the guidelines in the evaluation matrix or by using the optional part of the model "the triangle of comprehensive strategies" which allows for simpler and easy definition of the overall strategies (by simply using the list of interventions in the tables connected to different fields in the graph, such as illustrated in Table 7).

In the research, scenario 1 - comprehensive strategies - was defined using the predefined tables of the "triangle of comprehensive strategies" (illustrated in Table 7). According to the evaluation results, the urban site is located in field 2: average quality, low decay. The first two columns define the activities necessary for the correct valorisation of the heritage. The next three columns define the area of action, scope of action (useful to choose from the range of possible costs of interventions) and the priority of the actions, which helps to determine the possible phases of the implementation of the programme.

Scenario 2-the set of specific goals (for example: betterment of Fruition characteristics, Finance and Management aspects, Social characteristics, decreasing the Threats and pressures, but also any other goals can be chosen) — was based on the extraction of the guidelines from the evaluation matrix. The research used only the proposed model for the creation of the scenarios but it is possible to create the scenarios with any other method.

The next step is the comparison of the proposed scenarios. In both cases, the scenarios were evaluated by reapplying the evaluation matrix. At this point the results can also be integrated with some other prioritization methods.

The second phase consists of the comparison of the scores between different scenarios and of the present state (deducing the performance of the proposed interventions) or of the net benefit of the scenarios (performance related to the costs of the actions) based on the "heritage value for money" [37] perspective (Tables 8 and 9). 
Table 7. Indications of actions to perform for executing comprehensive strategies (the complete table is contained in [47]).

\begin{tabular}{|c|c|c|c|c|}
\hline \multicolumn{2}{|c|}{$\begin{array}{c}\text { Comprehensive strategies for urban sites } \\
\text { Field 2-average quality, low decay } \\
\end{array}$} & Area of action & $\begin{array}{l}\text { Scope of } \\
\text { action }\end{array}$ & Priority \\
\hline \multirow{8}{*}{$\begin{array}{l}\text { Actions of } \\
\text { physical } \\
\text { interventions on } \\
\text { the good } \\
\text { (conservation, } \\
\text { adaption, } \\
\text { reconstruction, } \\
\text { valorisation, } \\
\text { fruition...): }\end{array}$} & $\begin{array}{l}\text { - environmental conservation and } \\
\text { maintenance of built elements }\end{array}$ & - entire site & moderate & high \\
\hline & $\begin{array}{l}\text { - environmental conservation and } \\
\text { maintenance of natural elements } \\
\end{array}$ & - entire site & moderate & high \\
\hline & $\begin{array}{l}\text { - conservation of open public spaces } \\
\text { and their constitutional elements }\end{array}$ & - punctual and extensive & moderate & high \\
\hline & - conservation of green urban areas & - punctual and extensive & moderate & high \\
\hline & $\begin{array}{l}\text { - creation and positioning of } \\
\text { information presentation and } \\
\text { valorisation services }\end{array}$ & - $\quad$ punctual and extensive & moderate & medium \\
\hline & $\begin{array}{l}\text { improvement of fruition-definition } \\
\text { of route types - pedestrian, cycle, } \\
\text { driveways, mixed }\end{array}$ & - extensive & moderate & medium \\
\hline & $\begin{array}{l}\text { - organisation and improvement of } \\
\text { parking spaces }\end{array}$ & - punctual & moderate & medium \\
\hline & $\begin{array}{l}\text { - conservation of biodiversity and } \\
\text { ecological function }\end{array}$ & - mild scope & moderate & medium \\
\hline \multirow{3}{*}{$\begin{array}{l}\text { Actions of } \\
\text { physical } \\
\text { interventions on } \\
\text { the context of the } \\
\text { good: }\end{array}$} & $\begin{array}{l}\text { - improvement of public transport and } \\
\text { public infrastructures }\end{array}$ & - punctual and extensive & mild & medium \\
\hline & $\begin{array}{l}\text { - environmental improvement- } \\
\text { biological diversity and/or uniqueness } \\
\text { and ecological function }\end{array}$ & - $\quad$ punctual and extensive & mild & medium \\
\hline & $\begin{array}{l}\text { - interventions to ensure } \\
\text { hydrogeological safety_mild scope }\end{array}$ & - punctual and extensive & mild & medium \\
\hline \multirow{7}{*}{$\begin{array}{l}\text { Management } \\
\text { aspects related to } \\
\text { the good } \\
\text { (financial aspects, } \\
\text { network } \\
\text { organisation, } \\
\text { public } \\
\text { participation...): }\end{array}$} & $\begin{array}{l}\text { incentives for the activities of } \\
\text { research and divulgation of } \\
\text { information on the urban site }\end{array}$ & - continuous action & relevant & medium \\
\hline & - construction of management projects & - continuous action & relevant & high \\
\hline & 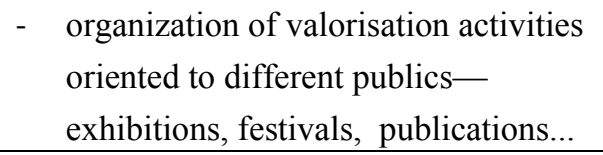 & - continuous action & relevant & high \\
\hline & $\begin{array}{l}\text { - improvement of fruition in network } \\
\text { with similar sites }\end{array}$ & - continuous action & relevant & high \\
\hline & $\begin{array}{l}\text { collaboration on open competitions, } \\
\text { public contracts and planning } \\
\text { agreements }\end{array}$ & - continuous action & relevant & high \\
\hline & $\begin{array}{l}\text { - activation of financial tools oriented } \\
\text { to improvement of management } \\
\text { action-fund-raising, taxation, awards... }\end{array}$ & - continuous action & relevant & high \\
\hline & $\begin{array}{l}\text { - definition of property rights including } \\
\text { public participation }\end{array}$ & - continuous action & relevant & high \\
\hline
\end{tabular}


Table 8. The verification of the score and performance of the two scenarios.

\begin{tabular}{|c|c|c|c|c|c|c|c|c|c|c|c|}
\hline \multirow[b]{2}{*}{ Thematic category: } & \multicolumn{3}{|c|}{ Evaluation before interventions } & \multicolumn{4}{|c|}{$\begin{array}{c}\text { Evaluation after interventions-scenario } 1- \\
\text { comprehensive strategies }\end{array}$} & \multicolumn{4}{|c|}{$\begin{array}{l}\text { Evaluation after } \\
\text { interventions-scenario 2-set of goals }\end{array}$} \\
\hline & $\begin{array}{l}\text { Quality } \\
\text { score }\end{array}$ & $\begin{array}{c}\text { Degradation } \\
\text { score } \\
\end{array}$ & $\begin{array}{l}\text { Total } \\
\text { score }\end{array}$ & $\begin{array}{c}\text { Quality } \\
\text { score }\end{array}$ & $\begin{array}{c}\text { Degradation } \\
\text { score } \\
\end{array}$ & $\begin{array}{l}\text { Total } \\
\text { score }\end{array}$ & $\begin{array}{l}\text { Diff. of } \\
\text { scores }\end{array}$ & $\begin{array}{l}\text { Quality } \\
\text { score }\end{array}$ & $\begin{array}{l}\text { Degradation } \\
\text { score }\end{array}$ & $\begin{array}{l}\text { Total } \\
\text { score }\end{array}$ & $\begin{array}{l}\text { Diff. of } \\
\text { scores }\end{array}$ \\
\hline $\begin{array}{l}\text { Physical-geographic } \\
\text { characteristics of } \\
\text { the context }\end{array}$ & $+28 / 33$ & $-/ 33$ & $+28 / 33$ & $+30 / 33$ & $-/ 33$ & $+30 / 33$ & +2 & $+30 / 33$ & $-/ 33$ & $+30 / 33$ & +2 \\
\hline $\begin{array}{l}\text { Historical-cultural } \\
\text { characteristics }\end{array}$ & $+27 / 39$ & $-2 / 12$ & $+25 / 39$ & $+33 / 39$ & $-/ 12$ & $+33 / 39$ & +6 & $+31 / 39$ & $-2 / 12$ & $+29 / 39$ & +4 \\
\hline $\begin{array}{l}\text { Intrinsic characteristics- } \\
\text { urban and architectural } \\
\text { characteristics }\end{array}$ & $+30 / 57$ & $-/ 30$ & $+30 / 57$ & $+30 / 57$ & $-/ 30$ & $+30 / 57$ & - & $+30 / 57$ & $-/ 30$ & $+30 / 57$ & - \\
\hline State of conservation & $+18 / 27$ & $-/ 27$ & $+18 / 27$ & $+22 / 27$ & $-/ 27$ & $+22 / 27$ & +4 & $+22 / 27$ & $-/ 27$ & $+22 / 27$ & +4 \\
\hline Fruition characteristics & $+6 / 27$ & $-12 / 27$ & $-6 / 27$ & $+24 / 27$ & $-/ 27$ & $+24 / 27$ & +30 & $+17 / 27$ & $-/ 27$ & $+17 / 27$ & +23 \\
\hline $\begin{array}{l}\text { Financing and } \\
\text { management aspects }\end{array}$ & $+34 / 105$ & $-24 / 105$ & $+10 / 105$ & $+80 / 105$ & $-/ 105$ & $+80 / 105$ & +72 & $+70 / 105$ & $-2 / 105$ & $+68 / 105$ & +58 \\
\hline Social characteristics & $+8 / 33$ & $-3 / 33$ & $+5 / 33$ & $+27 / 33$ & $-/ 33$ & $+27 / 33$ & +22 & $+21 / 33$ & $-/ 33$ & $+21 / 33$ & +16 \\
\hline Threats and pressures & $-1-$ & $-22 / 48$ & $-22 / 48$ & $-1-$ & $-14 / 48$ & $-14 / 48$ & +8 & $-/ 48$ & $-14 / 48$ & $-14 / 28$ & +8 \\
\hline Score & $+151 / 321$ & $-63 / 315$ & +88 & $+246 / 321$ & $-14 / 315$ & +232 & +144 & $+221 / 321$ & $-18 / 315$ & +203 & +115 \\
\hline
\end{tabular}


Table 9. Estimated costs of the interventions considered.

\begin{tabular}{ccc}
\hline Strategic activities & $\begin{array}{c}\text { Cost per category } \\
\text { comprehensive strategies }\end{array}$ & $\begin{array}{c}\text { Cost per category } \\
\text { scenario 2-set of goals }\end{array}$ \\
\hline Architectural and urban heritage & $15,000,000$ & $2,000,000$ \\
Infrastructure & $5,000,000$ & $5,000,000$ \\
Natural environment & $1,000,000$ & $1,000,000$ \\
Research & 500,000 & 500,000 \\
Aid for initiation of activity & 500,000 & 500,000 \\
\hline & $22,000,000$ & $9,000,000$ \\
\hline
\end{tabular}

In the case of the urban site of the city of Brseč, the most problematic results are Fruition characteristics, Financing and management aspects, Social characteristics and Threats and pressures. After the application of the comprehensive strategies, the state of the sites would show an important overall improvement - from a total score of $+151 / 321,-63 / 315$ to $+246 / 321,-14 / 315$ (difference of +144 points) with considerable improvement mostly in target categories, while only the category of Threats and pressures would remain negative, although improved. This performance could be achieved for (estimated) 22,000,000 euro, or the cost of 152,780 euro for a point and net benefit of 0.001 for 1,000 euro. Considering the extension of the site, the cost per unit is calculated to $2,445,000$ euro or 16,980 euro/score.

A proposed alternative was to dedicate the actions to the negative characteristics (chosen goals scenario). In this case lower conservation subsidies would be given while the actions would consider primarily fruition infrastructures, environmental improvement and management and public-oriented activities. After the application of indicated strategies, the state of the sites would show an important improvement-from a total score of $+151 / 321,-63 / 315$ to $+221 / 321,-18 / 315$ (a difference of +115 points) with considerable improvement mostly in problematic categories, while in the positive categories it's difficult to improve the extant much, as it has already been highly evaluated and depends mostly on historical factors. Only the category of Threats and pressures would remain negative although improved. This performance could be achieved for (an estimated) 9,000,000 euro, or the cost of 78,260 euro for a point and net benefit of 0.0015 for 1,000 euro. Considering the extension of the site, the cost per unit is calculated to $1,000,000$ euro or 8695 euro/score.

In the third phase the alternatives (scenarios) are put in order on the basis of the performance (Tables 10 and 11). To allow a comparison to be made regarding different objectives, the characteristics of the goods and the scores are articulated in significant indicators: urgency, cost, cost per unit, performance, cost per unit/score, finance and management performance, and cost for finance and management performance. It can be seen that although the comprehensive strategies bring major overall benefit, when the values of total cost, cost per unit, performance related to cost, and cost of achieving the goals of conservation and of stated goals are factored in, the partial intervention is actually the better option. This partial set of goals can be accepted where urgency is not present (as in the case of Brseč). 
Table 10. The comparison of scenarios of the comprehensive strategies and of the specific actions for the urban site of Brseč.

\begin{tabular}{lcc}
\hline & $\begin{array}{c}\text { Scenario 1-comprehensive } \\
\text { strategies }\end{array}$ & $\begin{array}{c}\text { Scenario 2-specific } \\
\text { actions }\end{array}$ \\
\hline Urgency & No & No \\
Cost (€) & $22,000,000$ & $9,000,000$ \\
Area (ha) & 9 & 9 \\
Cost per unit (ha) & $2,445,000$ & $1,000,000$ \\
Score before & $+151 / 321,-63 / 315$ & $+151 / 321,-63 / 315$ \\
Score after & $+246 / 321,-14 / 315$ & $+221 / 321,-18 / 315$ \\
Difference of score & +144 & +115 \\
Cost/diff. Score & 152,780 & 78,260 \\
Cost per unit/Score & 16,980 & 8,695 \\
Diff. score Intrinsic characteristics and & $+4 / 84$ & $+4 / 84$ \\
Conservation & & \\
Cost per unit/diff. score Intrinsic & 611,250 & 250,000 \\
characteristics and Conservation & & $+105 / 213$ \\
Diff. score Fruition, Finance and Management, & $+132 / 213$ & \\
Social, Threats & & 9,525 \\
Cost per unit/diff. score Fruition, Finance and & 18,525 & \\
Management, Social, Threats & & \\
\hline
\end{tabular}

Table 11. Order of alternatives based on performance.

\begin{tabular}{lccccccc}
\hline & Urgency & $\begin{array}{c}\text { Total } \\
\text { cost }\end{array}$ & $\begin{array}{c}\text { Cost } \\
\text { per unit }\end{array}$ & $\begin{array}{c}\text { Score } \\
\text { differ. }\end{array}$ & $\begin{array}{c}\text { Cost per } \\
\text { unit/Score } \\
\text { diff. }\end{array}$ & $\begin{array}{c}\text { Cost per unit/diff. for } \\
\text { Intrinsic charact. and } \\
\text { Conservation }\end{array}$ & $\begin{array}{c}\text { Cost per } \\
\text { unit/diff. } \\
\text { stated goals }\end{array}$ \\
\hline $\begin{array}{l}\text { Scenario 1- } \\
\text { comprehensive } \\
\text { strategies }\end{array}$ & - & 2 & 2 & 1 & 2 & 1 & 2 \\
$\begin{array}{l}\text { Scenario 2- } \\
\text { specific actions }\end{array}$ & - & 1 & 1 & 2 & 1 & 1 & 1 \\
\hline
\end{tabular}

\subsection{The Results of the Evaluation}

After the evaluation of the characteristics of the site using the Evaluation matrix, the characteristics of the extant are determined and two development scenarios are formed-one based on the overall strategies and the other on the set of goals. Reapplying the matrix, the scenarios are evaluated, with the more efficient resulting in the set of goals scenario (which differs from other cases in which the model was tested).

Even if the comprehensive strategies bring higher performance in betterment of the state of the heritage, the partial intervention is, in this case, the more efficient option for the betterment of the intrinsic characteristics and the valorisation of the heritage asset.

This result, although somehow surprising, is interesting in showing that, in this case, targeted actions can be more efficient than an overall action, and is especially important in the case of restricted budgets, typical of the present situation.

The application of the proposed evaluation model found that even when operating with a limited possibility of management and interventions - limited budget and a moderately preserved extant which currently lacks the creative vision for its development - when well chosen, the valorisation activities (physical and managerial) can bring substantial improvement in all development categories and to 
different social sectors, opening new cultural, creative, productive and leisure opportunities while protecting and improving the state and the understanding of the spatial heritage.

\section{Conclusions}

The aim of the article was to illustrate the shift from a contemplative ("bounding") view to a dynamic-planning view of the heritage and the model that can help its creative use in sustainable development. This model is created on the basis of evaluation models as a decision-aid tool (such as Leopold matrices, the Kalman method, EIA and SEA), capable of analysis, diagnosis of the spatial heritage (and so helping the creation of development scenarios in value-focused orientation), evaluation of alternatives and monitoring of the state of the heritage.

Integration of conservation with planning poses the basis of sustainability of heritage conservation interventions by connecting social, environmental and economic sustainability. As heritage is a complex process, its understanding has to consider different aspects from many disciplinary fields, and some of those main basic issues are addressed in the first part of the article.

The second part of the article illustrates some important evaluation models and their use in decision-making. It can be seen that evaluations are strong decision-aid tools with ample opportunities for employment and development in a perspective of not only evaluating existing alternatives, but also of addressing the state of the extant (analysis), identifying positive and negative traits (often allowing for diagnosis and recommendations) and allowing for the measurement of improvements (or lack thereof) obtained by the proposed plan. These characteristics indicate that with some work, evaluations can be a basis for the creation of a tool that can orient and help the management process for spatial heritage. Obviously public participation requires the will of administrative and political structures to include the public (expert or general) in the decision-making processes (something still not regularly employed on many occasions). Some main characteristics of this proposed model are illustrated.

The third part brings an example of the application model. The site is very difficult because it doesn't present any obvious negative traits but generally lacks management and vision. So the question "what to do with the spatial heritage to have sustainable development based on the characteristics of the landscape?" doesn't have an immediate, obvious and simple answer. The use of the model helped with the definition of the efficient scenario for sustainable development based on the valorisation of the heritage.

The proposed model is constructed for real function, so it had to be: logical, rational, coherent, flexible, modular, able to handle mixed uncertain data and able to be integrated with other specific techniques. The model works for different types of heritage assets and is applicable in practical cases. However, some problem areas were noted in the design and its implementation.

Although the theoretical part deals with the theme of heritage as a social process and not a list of categories, for practical reasons it incorporates the definition of heritage categories based on the homogeneity of the characteristics to be analysed. This division into seven categories of assets can be changed if necessary. The breakdown in the thematic modules is strongly linked both to the concepts of sustainable development and the territorial reality. In other contexts, evaluation issues and indicators should be verified before using the evaluation matrix. The same applies to the weights of 
indicators defined by the analysis of impacts by sectors, but would be better defined by a group of experts from different disciplines.

Although the model is specifically built to handle mixed data and uncertainty, it should be noted that the difficulty in obtaining data may vary due to the existence of earlier multidisciplinary studies. Obviously it is easier to carry out the analysis and evaluation of items for which the data are already organized. The model provides for integration with analytical techniques for specific themes; in the case of poorly documented assets, the work of compiling matrices can become an important commitment.

The model also allows the possibility of analysis of assets not yet registered by also providing possible negative evaluations of the characteristics, in order to allow the analysis and verification of potential assets with a precautionary view. These types of assets are usually little studied, therefore compiling matrices can be challenging.

The best functioning of the model would come in the long term, integrated with databases of administrative structures. This is particularly true for the creation of strategies to be integrated into development plans and for long-term monitoring of the state of assets, re-evaluating the heritage on a regular basis with tracking of historic trends and predicting the tendencies.

The model would be best implemented during the creation of the strategic planning documentation, especially for vast heritage elements such as cultural landscapes and other extensive sites. The strategic application of the evaluation model can comprise comparisons of different sites and different management options for the sites in question. In the case of the evaluation of a single site, different scenarios could be evaluated, and the financial analysis would have to be of foremost importance.

The comprehensive strategies for the goods often foresee (especially in cases of very large assets such as cultural landscape) important investments. For this the model should be integrated with other management tools such as management and financial plans. The lack of data on investment costs and management of assets was also found during the research, for the most part due to the lack of significant investments in interventions, disorganisation and lack of data transparency in the processes of intervention procedures.

The usefulness for the public would be in providing the opportunity to use existing data and allowing verification of the different scenarios, for example online. Another aspect of the use of such a model, for the public administration, could be the systematic periodic evaluation of the extant heritage in the perspective of monitoring the state of the heritage elements, possibly giving alerts at certain limits of degradation. For a private investor, it is expected to be of great interest to have the opportunity to consult, possibly online, the database with evaluated elements with all relevant data necessary to form the investment proposals needed for the first business analysis.

These possible uses indicate the need to create an information technology platform integrated with other data regarding cultural heritage and spatial development. The integrated platform, by highlighting impacts of managerial choices and allowing for transparent information and communication, could facilitate the use of data and of the evaluation model for the public, administrations and investors, and in the case of programmed accords or funds requests. 


\section{Conflicts of Interest}

The author declares no conflict of interest.

\section{References}

1. Berger, P.L.; Luckmann, T. La realtà come costruzione sociale; Il Mulino: Bologna, IT, 2002; original Eds. Berger, P.L., Luckmann, T. The Social Construction of Reality; Anchor Books: Garden City, NY, USA, 1966.

2. Values and Heritage Conservation. Research Report; Avrami, E., Mason, R., de la Torre, M., Eds.; The Getty Conservation Institute: Los Angeles, CA, USA, 2000. Available online: http://www.getty.edu/conservation/publications/pdf_publications/valuesrpt.pdf, (accessed on 10 October 2012).

3. Lichfield, N. Economics in Urban Conservation; Cambridge University Press: Cambridge, UK, 1988; p. 65.

4. Griswold, W. Cultures and Societies in a Changing World; Pine Forge Press: Thousand Oaks, CA, USA, 1994.

5. Ashworth, G.J.; Howard, P. Dimensions and Scope of Heritage. In European Heritage Planning and Management; Ashworth, G.J., Howard, P., Eds.; Intellect: Exeter, UK, 1999; p. 26.

6. Carta, M. L'armatura culturale del territorio. Il patrimonio culturale come matrice di identità e strumento di sviluppo; FrancoAngeli: Milano, Italy, 2002.

7. Mela, A.; Belloni, M.C.; Davico, L. Sociologia e progettazione del territorio; Carocci editore: Roma, Italy, 2000; p. 175.

8. Nijkamp, P.; Riganti, P. Assessing cultural heritage benefits for urban sustainable development. Int. J. Serv. Technol. Manag. 2008, 10, 29-37.

9. UNESCO Universal Declaration on Cultural Diversity (Paris, 2001). Available online: http://unesdoc.unesco.org/images/0012/001271/127160m.pdf (accessed on 10 October 2012).

10. Mossetto, G. L'economia delle città d'arte. Modelli di sviluppo a confronto, politiche e strumenti di intervento; EtasLibri: Milano, Italy, 1992; p. 87.

11. Greffe, X. La gestione del patrimonio culturale; FrancoAngeli: Milano, Italy, 2003; pp. 50-73.

12. Fusco Girard, L.; Nijkamp, P. La valutazione nel livello tattico ed attuativo/gestionale dello sviluppo sostenibile. In Le valutazioni per lo sviluppo sostenibile della città e del territorio; Fusco Girard, L., Nijkamp, P., Eds.; FrancoAngeli: Milano, Italy, 1997; pp. 98-122.

13. Mossetto, G.; Vecco, M. L'economia e la gestione del patrimonio edificato. In Economia del patrimonio monumentale; Mossetto, G., Vecco, M., Eds.; FrancoAngeli: Milano, Italy, 2001; pp. 25-26.

14. Schuster, J.M. Inciting Preservation. In Preserving the Built Heritage. Tools for Implementation, Salzburg Seminar; Schuster, J.M., de Monchaux, J., Riley, C.A., II, Eds.; University Press of New England: Hanover, RD, London, UK, 1997; pp. 49-80.

15. Levine, M.V. A Third-World City in the First World: Social Exclusion, Racial Inequality, and Sustainable Development in Baltimore, Maryland. In The Social Sustainability of Cities. Diversity 
and The Management of Change; Polese, M., Stren, R., Eds.; University of Toronto Press Incorporated: Toronto, Canada; Buffalo, NY, USA; London, UK, 2000.

16. Moretti, A. Destination Management and the Reuse of Cultural Artistic Heritage. In Economia del Patrimonio Monumentale; Mossetto, G., Vecco, M., Eds.; FrancoAngeli: Milano, Italy, 2001; pp. 60-82.

17. Mossetto, G. L'economia delle città d'arte. Modelli di sviluppo a confronto, politiche e strumenti di intervento; EtasLibri: Milano, Italy, 1992.

18. Coote, A.; Lenaghan, J. Citizens' Juries: Theory into Practice; Institute for Public Policy Research: London, UK, 1997.

19. Landry, C. The Creative City. A Toolkit For Urban Innovators; Eartscan Publications: London, UK, 2000.

20. Riqualificare la città con gli abitanti; De Eccher, A., Marchigiani, E., Marin, E., Eds.; EdicomEdizioni: Monfalcone, Italy, 2005.

21. Stagl, S. Il Ruolo Della Valutazione Multicriteria Partecipata Nella Pianificazione Energetica. In Energia, Bellezza, partEcipazione: La Sfida Della Sostenibilità. Valutazioni Integrate Tra Conservazione e Sviluppo; Fusco Girard, L., Nijkamp, P., Eds.; FrancoAngeli: Milano, Italy, 2004; p. 263.

22. Deliberative Democracy. Essays on Reason and Politics; Bohman, J., Rehg, W., Eds.; The MIT Press: Cambridge, MA, USA, 1997.

23. Elster, J. The Market and the Forum: Three Varieties of Political Theory. In Deliberative Democracy. Essays on Reason and Politics; Bohman, J., Rehg, W., Eds.; The MIT Press: Cambridge, MA, USA, 1997; pp. 14-15.

24. Keeney, R.L. Value-Focused Thinking. A Path to Creative Decisionmaking; Harvard University Press: Cambridge, MA, USA, 1992.

25. European Commission, Strategic Environmental Assessment (SEA) 2001/42/EC. Available online: http://ec.europa.eu/environment/eia/sea-legalcontext.htm (accessed on 20 October 2012).

26. Zeleny, M. Multiple Criteria Decision Making; McGraw-Hill Book Company: New York, NY, USA, 1982.

27. Pickard, R.; de Thyse, M. The Management of Historic Centres: Towards a Common Goal. In Management of Historic Centres; Pickard, R., Ed.; Spoon Press: London, UK, 2001.

28. Lowenthal, D. Stewarding the Past in a Perplexing Present. In Values and Heritage Conservation. Research Report; Avrami, E., Mason, R., de la Torre, M., Eds.; The Getty Conservation Institute: Los Angeles, CA, USA, 2000.

29. Leopold, L.B.; Clarke, F.E.; Hanshaw, B.B.; Balsley, J.R. A Procedure for Evaluating Environmental Impact. United States Department of the Interior, Washington, Geological Survey 1971, Circular n. 645. Available online: http://eps.berkeley.edu/people/lunaleopold/\%28118\% $29 \% 20$ A $\% 20$ Procedure $\% 20$ for $\% 20$ Evaluating\%20Environmental\%20Impact.pdf (accessed on 10 October 2012).

30. Pypaert, P.; Carollo, S. Valutazione ambientale e sviluppo sostenibile: il caso di Omišalj in Croazia. Available online: http://host83-40-static.86-94-b.business.telecomitalia.it/export/sites/default/archivio/ allegati/vari/vas_seminario_pypaert_carollo.pdf (accessed on 4 September 2013), (in Italian).

31. Kalman, H. The Evaluation of Historic Buildings; Parks Canada: Ottawa, Canada, 1979. 
32. Lichfield, N. Economics in Urban Conservation; Cambridge University Press: Cambridge, UK, 1988; pp. 178-181.

33. Website of Parks Canada. Available online: http://www.pc.gc.ca/progs/beefp-fhbro/itm1-/ index_e.asp (accessed on 20 October 2012).

34. Website of National Park Service U.S. Department of the Interior. Available online: http://www.nps.gov/grko/parkmgmt/planning.htm (accessed on 20 October 2012).

35. Campeol, G.; Pizzinato, C. Metodologia per la valutazione dell'impatto archeologico; Archeologia e Calcolatori 2007, 18, pp. 273-292. Available online: http://soi.cnr.it/archcalc/ indice/PDF18/14_Campeol.pdf (accessed on 10 June 2012).

36. European Commission, Environmental Impact Assessment (EIA) Directive 85/337/EEC, 97/11/EC, 2003/35/EC, 2009/31/EC codified in 2011/92/EU. Available online: http://ec.europa.eu/ environment/eia/eia-legalcontext.htm (accessed on 10 June 2012).

37. Lichfield, N. Economics in Urban Conservation; Cambridge University Press: Cambridge, UK, 1988.

38. Mrak, I. Multicriteria Evaluation for Cultural Heritage Management from a Sustainable Spatial Development Perspective. Ph.D. Dissertation, University of Nova Gorica Graduate School, Venice, Italy, 2011; pp.120-122.

39. Mrak, I. Multicriteria Evaluation for Cultural Heritage Management from a Sustainable Spatial Development Perspective. Ph.D. Dissertation, University of Nova Gorica Graduate School, Venice, Italy, 2011; pp. 134-141.

40. Mrak, I. Multicriteria Evaluation for Cultural Heritage Management from a Sustainable Spatial Development Perspective. Ph.D. Dissertation, University of Nova Gorica Graduate School, Venice, Italy, 2011; pp. 545-553.

41. Hinloopen, E.; Nijkamp, P. Qualitative Multiple Criteria Choice Analysis. The Dominant Regime Method; Vrije Universiteit: Amsterdam, The Netherlands, 1986.

42. Janssen, R.; van Herwijnen, M. Decision Support for Discrete Choice Problems: the DEFINITE Program; Institute for Environmental Studies (IVM), Vrije Universiteit: Amsterdam, The Netherland, 2006.

43. Spatial Regulation Plan of the Municipality Mošćenička Draga (SN PGŽ 36/07). Available online: http://www.zavod.pgz.hr/docs/zzpuHR/docsplanovigrad/41/ppuo-moscenicka-draga.pdf (accessed on 20 June 2012).

44. Directorate for the Protection of Cultural Heritage, Conservation Department in Rijeka, Ministry of Culture, Republic of Croatia. Konzervatorska studija prostora Općine Mošćenička Draga, 2000.

45. Viškanić, D. Brseč - grbovi, pečati, žigovi, Brseč. Liburnijske teme: zbornici Čakavskog sabora 1994, N.8, 94-100, (in Italian).

46. Staraj, R. Općina Moščenička Draga. Slike Sjećanja I Života 1890-2006, Il Comune di Draga di Moschiena. Immagini di Vita e Memoria 1890-2006, Gemeinde Mošćenička Draga. Erinnerungs Und Lebensbilder 1896-2006, Commune of Mošćenička Draga. The Images of Memories and Life, 1890-2006 (in Italian); Adamić, Zajednica Talijana Mošćenička Draga: Rijeka, Croatia, 2007; p. 34. 
47. Mrak, I. Multicriteria Evaluation for Cultural Heritage Management from a Sustainable Spatial Development Perspective. Ph.D. Dissertation, University of Nova Gorica Graduate School, Venice, Italy, 2011; pp. 205-237.

(C) 2013 by the authors; licensee MDPI, Basel, Switzerland. This article is an open access article distributed under the terms and conditions of the Creative Commons Attribution license (http://creativecommons.org/licenses/by/3.0/). 